\title{
Expedition 316 summary $^{\mathbf{1}}$
}

\author{
E.J. Screaton, G. Kimura, D. Curewitz, and the Expedition 316 Scientists $^{2}$
}

\section{Chapter contents}

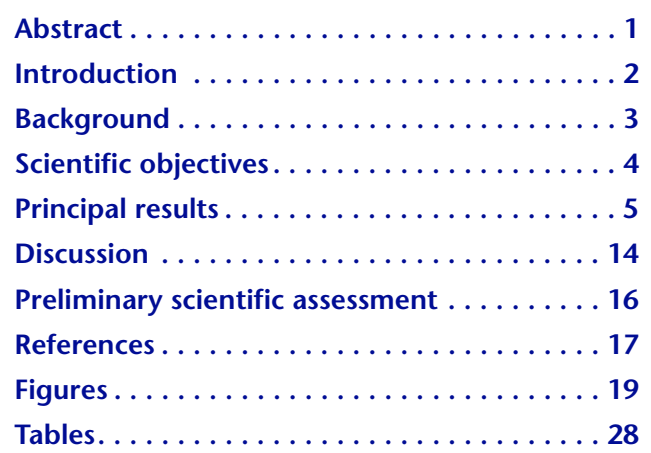

1Screaton, E.J., Kimura, G., Curewitz, D., and the Expedition 316 Scientists, 2009. Expedition 316 summary. In Kinoshita, M., Tobin, H., Ashi, J., Kimura, G., Lallemant, S., Screaton, E.J., Curewitz, D., Masago, H., Moe, K.T., and the Expedition 314/315/316 Scientists, Proc. IODP, 314/315/316: Washington, DC (Integrated Ocean Drilling Program Management International, Inc.). doi:10.2204/iodp.proc.314315316.131.2009 ${ }^{2}$ Expedition 314/315/316 Scientists' addresses.

\section{Abstract}

Integrated Ocean Drilling Program (IODP) Expedition 316 is part of the Nankai Trough Seismogenic Zone Experiment (NanTroSEIZE). This coordinated multiexpedition drilling project is designed to investigate fault mechanics and seismogenesis along subduction megathrusts through direct sampling, in situ measurements, and long-term monitoring in conjunction with allied laboratory and numerical modeling studies.

Expedition 316 was designed to evaluate the deformation, inferred depth of detachment, structural partitioning, fault zone physical characteristics, and fluid flow at the frontal thrust and at the shallow portion of the megasplay system. To accomplish these objectives, drilling was conducted at two sites in the megasplay region, one within the fault zone and one in the slope basin seaward of the megasplay. Two sites were also drilled within the frontal thrust region. During IODP Expedition 314, two of these sites were characterized using logging while drilling. IODP Site C0004 is located along the slope of the accretionary prism landward of the inferred intersection of the megasplay fault zone with the seafloor. Drilling at this site examined the youngest sediments on the slope overlying the accretionary prism; these sediments consist of slowly deposited marine sediments and redeposited material from upslope. This redeposited material provides information about past slope failures, which may be related to past megasplay movement, earthquakes, and tsunamigenesis. The accretionary prism was sampled, and the megasplay fault zone was successfully drilled. The top of the prism corresponds to a prominent unconformity (age gap $=\sim 1$ m.y.) that displays mineralization by pyrite and other minerals. Structural observations of core material from the fault zone and two age reversals suggested by nannofossils indicate a complex history of deformation. Sediments under the fault zone were sampled to understand their deformation, consolidation, and fluid flow history. Drilling at IODP Site C0008 targeted the slope basin seaward of the megasplay fault. This basin records the history of fault movement. In addition, sediment layers within this basin provide a reference for sediment underthrusting the splay fault zone at Site C0004. Drilling at IODP Sites C0006 and C0007 allowed examination of the frontal thrust region. At Site C0006, several fault zones within the prism were penetrated before drilling was stopped because of poor conditions. The plate boundary frontal thrust was successfully drilled, and thrust fault material 
ranging from breccia to fault gouge was successfully recovered at Site C0007.

\section{Introduction Overview of NanTroSEIZE}

Subduction zones account for $90 \%$ of global seismic moment release, generating damaging earthquakes and tsunamis with potentially disastrous effects on heavily populated coastal areas (e.g., Lay et al., 2005). Understanding the processes that govern the strength, nature, and distribution of slip along these plate boundary fault systems is a crucial step toward evaluating earthquake and tsunami hazards. More generally, characterizing fault behavior at all plate boundary types through direct sampling, near-field geophysical observations, and measurement of in situ conditions at depths of coseismic slip is a fundamental and societally relevant goal of modern earth science.

To this end, several recent and ongoing drilling programs have targeted portions of active plate boundary faults that have either slipped coseismically during large earthquakes or nucleated smaller events. These efforts include the San Andreas Fault Observatory at Depth (Hickman et al., 2004), the Taiwan-Chelungpu Drilling Project (Ma, 2005), and the Integrated Ocean Drilling Program (IODP) Nankai Trough Seismogenic Zone Experiment (NanTroSEIZE) drilling (Tobin and Kinoshita, 2006a, 2006b).

NanTroSEIZE is a multiexpedition, multistage IODP effort focused on understanding the mechanics of seismogenesis and rupture propagation along subduction plate boundary faults. The drilling program represents a coordinated effort to sample and instrument the plate boundary system at several locations offshore the Kii Peninsula (Figs. F1, F2), with the main objectives of understanding (Tobin and Kinoshita, 2006a, 2006b) the following:

- The aseismic-seismic transition of the megathrust fault system,

- Processes of earthquake and tsunami generation, and

- The hydrologic behavior of the plate boundary.

The drilling program will evaluate a set of core hypotheses through a combination of riser and riserless drilling, long-term observatories, and associated geophysical, laboratory, and numerical modeling efforts. The following hypotheses are paraphrased from the original proposals and outlined in Tobin and Kinoshita (2006a, 2006b):
1. Systematic, progressive material and state changes control the onset of seismogenic behavior on subduction thrusts.

2. Subduction megathrusts are weak faults.

3. Plate motion is accommodated primarily by coseismic frictional slip in a concentrated zone (i.e., the fault is locked during the interseismic period).

4. Physical properties of the plate boundary system change with time during the earthquake cycle.

5. A significant, laterally extensive fault system (the "megasplay" fault; Park et al., 2002) slips in discrete events that may include tsunamigenic slip during great earthquakes. During the interseismic period, the megasplay remains locked and accumulates strain.

Sediment-dominated subduction zones such as the East Aleutian, Cascadia, and Nankai margins are characterized by repeated occurrences of great earthquakes of $>$ M 8.0 (Ruff and Kanamori, 1983). Although the causative mechanisms are not well understood (e.g., Byrne et al., 1988; Moore and Saffer, 2001; Saffer and Marone, 2003), the updip limit of the seismogenic zones at these margins is thought to correlate with a topographic break along the outer rise (e.g., Byrne et al., 1988; Wang and $\mathrm{Hu}, 2006$ ). Accretionary prisms in these subduction zones are separated into two parts by this topographic break (Wang and $\mathrm{Hu}, 2006$; Kimura et al., 2007a), and the inner and outer wedges are located above the seismogenic plate boundary and aseismic décollement, respectively.

At the Nankai Trough, high-resolution images of the outer rise from seismic reflection profiles clearly document a large out-of-sequence thrust (OOST) fault system (the megasplay fault after Park et al., 2002) that branches from the plate boundary décollement within the coseismic rupture zone of the 1944 Tonankai M 8.2 earthquake (Fig. F2). Several lines of evidence indicate that the megasplay system is active and may accommodate an appreciable component of plate boundary motion. However, the partitioning of strain between the lower plate interface (the décollement zone) and the megasplay system and the nature and mechanisms of fault slip as a function of depth and time on the megasplay are not understood. As stated in the fifth hypothesis above, one of the first-order goals in characterizing the seismogenic zone along the Nankai Trough-and one which bears on understanding subduction zone megathrust behavior globally-is to document the role of the megasplay fault in accommodating plate motion and to characterize its mechanical and hydrologic behavior. 
NanTroSEIZE Stage 1 consisted of three coordinated riserless drilling expeditions to drill several sites across the continental slope and rise offshore the Kii Peninsula, within the inferred coseismic slip region of the 1944 Tonankai M 8.2 earthquake (Figs. F1B, F2) (Tobin and Kinoshita, 2006a, 2006b). The first of these was a logging-while-drilling (LWD) expedition that served as a geophysical baseline (IODP Expedition 314: LWD Transect; D/V Chikyu) to define physical properties, lithology, and structural information in advance of coring operations. This was followed by a coring expedition (IODP Expedition 315: Megasplay Riser Pilot; Chikyu) that sampled the materials and characterized in situ conditions within the accretionary prism to a depth of 458 meters below seafloor (mbsf) at Site C0001 (proposed Site NT2-03) and 1057 mbsf at Site C0002. This expedition (IODP Expedition 316; Shallow Megasplay and Frontal Thrusts; Chikyu) was designed to characterize two major thrust fault systems at relatively shallow depths where they are accessible to riserless drilling (Table T1).

\section{Background}

\section{Geological setting}

The Nankai Trough is formed by subduction of the Philippine Sea plate to the northwest beneath the Eurasian plate at a rate of $\sim 4 \mathrm{~km} / \mathrm{m}$.y. (Seno et al., 1993). The convergence direction is approximately normal to the trench, and sediments of the Shikoku Basin are actively accreting at the deformation front. The Nankai Trough is among the most extensively studied subduction zones in the world, and great earthquakes during the past 1300 or more years are well documented in historical records (e.g., Ando, 1975). The Nankai Trough has been selected as a focus site for studies of seismogenesis by IODP, the Japanese Coordinating Committee for Earthquake Prediction, and the U.S. MARGINS initiative based on the wealth of geological and geophysical data available, a long historical record of great $(M>8.0)$ earthquakes, and direct societal relevance of understanding tsunamis and earthquakes that have had, and will have, great impact on nearby heavily populated coastal areas.

The Kumano Basin region, off Kii Peninsula (Fig. F1A, F1B), was chosen for drilling based on three criteria: (1) the updip end of the seismogenic zone is well defined based on slip in past great earthquakes, (2) seismic imaging presents clear drilling targets, and (3) deep targets are within the operational limits of riser drilling by the Chikyu (i.e., maximum of $2500 \mathrm{~m}$ water depth and $7000 \mathrm{mbsf})$. In the Kumano Basin, the seismogenic zone lies at $\sim 6000$ mbsf (Na- kanishi et al., 2002). Slip inversion studies suggest that only in this area of the Nankai Trough did past coseismic rupture clearly extend shallow enough for drilling (Ichinose et al., 2003; Baba and Cummins, 2005), and an updip zone of large slip (a potential asperity) has been identified and targeted (Fig. F1B). Coseismic slip during events like the 1944 Tonankai M 8.2 earthquake likely occurred on the megasplay fault rather than on the décollement beneath it, though slip on either plane is consistent with the available data. The megasplay fault, therefore, is a primary drilling target equal in importance to the basal décollement zone.

The region offshore the Kii Peninsula on Honshu Island has been identified as the best location for seismogenic zone drilling for several reasons. First, the rupture area of the most recent great earthquake, the 1944 Tonankai event, is well constrained by seismic and tsunami waveform inversions (e.g., Tanioka and Satake, 2001; Kikuchi et al., 2003). A horizon of significant coseismic slip is reachable by drilling with the Chikyu. Second, the region offshore the Kii Peninsula is generally typical of the Nankai margin in terms of heat flow and sediment on the incoming plate. This is in contrast to the area offshore Cape Muroto where previous Deep Sea Drilling Project and Ocean Drilling Program (ODP) drilling has focused and where both local stratigraphy associated with basement topography and anomalously high heat flow have been documented (Moore, Taira, Klaus, et al., 2001; Mikada, Moore, Taira, Becker, Moore, and Klaus, 2005). Third, ocean bottom seismometer campaigns and onshore high-resolution geodetic studies (though of short duration) indicate significant interseismic strain accumulation (e.g., Miyazaki and Heki, 2001; Obana et al., 2001).

As noted above, the megasplay, a large OOST, branches from the master décollement $\sim 50 \mathrm{~km}$ landward of the trench along the drilling transect and forms the trenchward boundary of the Kumano Basin. This forearc basin is filled by turbiditic sediments with a maximum thickness of $\sim 2000 \mathrm{~m}$. A pronounced continuous ridge of topography extending $>120 \mathrm{~km}$ along strike is evident in swath-bathymetric and multichannel seismic data and is likely related to splay fault slip. Remotely operated vehicle (ROV) and submersible surveys reveal a very steep slope on both sides of the ridge, suggesting recent activity (Ashi et al., 2002; J. Ashi, unpubl. data). This fault has been termed a megasplay because it differs markedly from other OOSTs in several respects:

- It is continuous along strike, is associated with a significant break in seafloor slope, and is a strong seismic reflector, suggesting that it is a first-order structural element of the margin. 
- Significant long-term slip is documented by sequence boundaries and progressive landward tilting of strata in the Kumano Basin as observed in seismic reflection data (Fig. F2).

- The megasplay separates rocks with significantly higher seismic velocity on its landward side from rocks of lower seismic velocity toward the trench, suggesting that it represents a major mechanical discontinuity (Nakanishi et al., 2002).

- It is geographically coincident with the updip termination of slip during the 1944 Tonankai event, as inferred from tsunami (Tanioka and Satake, 2001; Baba and Cummins, 2005) and seismic (Kikuchi et al., 2003; Ichinose et al., 2003) waveform inversions and recent structural studies, which indicate that it may have experienced coseismic slip (e.g., Park et al., 2002).

Mechanical arguments further suggest that the megasplay is the primary coseismic plate boundary near the updip terminus of slip (e.g., Kame et al., 2003; Wang and $\mathrm{Hu}, 2006)$.

Subduction zones like the Nankai Trough, on which great earthquakes $(M>8.0)$ occur, are especially favorable for study because the entire width (dip extent) of the seismogenic zone ruptures in each great event, so the future rupture area is more predictable than for smaller earthquakes. The Nankai Trough region is among the best-studied subduction zones in the world. It has a $1300 \mathrm{y}$ historical record of recurring and typically tsunamigenic great earthquakes, including the 1944 Tonankai M 8.2 and 1946 Nankaido M 8.3 earthquakes (Ando, 1975; Hori et al., 2004). The rupture area and zone of tsunami generation for the 1944 event are now reasonably well understood (Ichinose et al., 2003; Baba et al., 2006). Land-based geodetic studies suggest that the plate boundary thrust here is strongly locked (Miyazaki and Heki, 2001). Similarly, the relatively low level of microseismicity near the updip limits of the 1940s earthquakes (Obana et al., 2001) implies significant interseismic strain accumulation on the megathrust; however, recent observations of very low frequency earthquake event swarms apparently taking place within the accretionary prism in the drilling area (Obara and Ito, 2005) demonstrate that interseismic strain is not confined to slow elastic strain accumulation.

The outer accretionary wedge seaward of the 1944 earthquake seismogenic zone is characterized by strongly deformed fold-and-thrust belts above the aseismic plate boundary. Similar spatial and geometric relationships are commonly observed at other accretionary prisms (Plafker, 1972). The mechanical relationship between great earthquake slip in seismogenic zones and slip and deformation in the outer wedge is not well understood. However, Wang and $\mathrm{Hu}$ (2006) proposed that the forearc region can be described as a "dynamic critical wedge," and recent discoveries of low frequency events within the accretionary wedge (Ito and Obara, 2006) suggest that deformation and slip may occur episodically as both high-frequency postseismic events or as much lower frequency "slower" interseismic events. These factors contribute to both the evolution of the margin architecture and to the behavior of the system today (e.g., Park et al., 2002).

\section{Seismic studies and site survey data}

A significant volume of site survey data has been collected in the drilling area, including multiple generations of two-dimensional seismic reflection (e.g., Park et al., 2002), wide-angle refraction (Nakanishi et al., 2002), passive seismicity (e.g., Obara et al., 2004), heat flow (Yamano et al., 2003), side-scan sonar, and swath bathymetry and submersible and ROV dive studies (Ashi et al., 2002). In 2006, Japan and the United States conducted a joint three-dimensional (3-D) seismic reflection survey over a $\sim 11 \mathrm{~km} \times 55 \mathrm{~km}$ area, acquired by PGS Geophysical, an industry service company. This 3-D data volume is the first deeppenetration fully 3-D marine survey ever acquired for basic research purposes and has been used to refine selection of drill sites and targets, define the regional structures and seismic stratigraphy, analyze subsurface physical properties through seismic attribute studies, and assess drilling safety. Further, these data will be used in conjunction with physical properties and geophysical data obtained from core analyses and LWD to allow extensive and high-resolution integration of core, logs, and seismic data.

\section{Scientific objectives}

The first target of Expedition 316 was the shallow portion of the megasplay fault system, just seaward of the break in slope marking the boundary between the inner and outer accretionary wedge (Fig. F2). The scientific objectives of drilling the shallow portion of the megasplay fault system are as follows:

- Clarify the character and behavior of the shallow portion of the megasplay:

- Is the megasplay an active blind thrust or an inactive fault?

- Is there evidence for past seismogenic slip, supporting contention that the megasplay is the primary candidate for the source of great earthquakes and tsunamis?

- Clarify the slip and deformation mechanisms in the region above the (inferred) unstable seismogenic fault. 
- Clarify the relationship between fluid behavior, slip, and deformation along the megathrust.

- Clarify the evolutionary development of the splay fault.

The second target of Expedition 316 was the main frontal thrust at the seaward edge of the accretionary wedge (Fig. F3). Based on seismic data and submersible studies, this thrust is thought to have placed moderately consolidated, presumably older clastic rocks over weak and unlithified late Pleistocene trench section clastic sediments (Ashi et al., 2002). Two sites were drilled in this area to achieve the following objectives:

- Clarify the function of the frontal thrust with respect to large earthquakes:

- Do great earthquakes trigger slip along this fault plane, and if so, are they tsunamigenic?

- Does the frontal thrust generate low-frequency events or does it creep during the interseismic period?

- Evaluate the relationship between fluid behavior and slip and deformation.

- Assess the evolution of the frontal thrust from its birth to death.

\section{Operational strategy}

Two sites were drilled to investigate the shallow region of the megasplay. Site C0004 was selected during Expedition 314 (LWD) as an alternate to Site C0003 (proposed Site NT2-01B), where the target could not be reached (Kinoshita et al., 2008). Site C0004 was projected to cross the splay fault at $\sim 300$ mbsf; total depth (TD) was 400 mbsf in order to sample the underthrust material. Site C0008 was originally proposed as a contingency site (proposed Site NT2-10) to examine the slope sediment seaward of Site C0004. This site was selected as the last site of Expedition 316 because it represented the best balance between science objectives and time available (Fig. F4). Results from Site C0008 will help to assess the timing and relative age of past fault motions via identification of provenance and age of deposited material and the age across any disconformities between newly deposited sediments and older uplifted fault blocks. Numerous postcruise studies of fault and wall rock frictional properties will test ideas about fault zone strength and sliding stability. The permeability and physical properties of this material will also help interpretation of the fluid flow and consolidation response to splay fault movement as the slope basin sediments are progressively underthrust.

Core samples collected during Expedition 316 allow description of lithology and structure, provide age control through paleontological and paleomagnetic analysis, and provide samples for interstitial water, microbiology, and shipboard and postcruise physical property and geotechnical studies. In situ temperature measurements provide an important control for thermal models of the subduction zone (Table T2). Shipboard and postcruise results, when integrated with results from other NanTroSEIZE expeditions, will characterize physical properties, strength, frictional properties and behavior, composition, and structure of the slope sediments, hanging wall, and footwall of the splay fault and frontal thrust. Development of the fault zones at shallow depths will also be compared to drilling of the splay fault at greater depths at Sites C0001 and C0002 in later NanTroSEIZE expeditions.

\section{Principal results Site $\mathrm{CO004}$}

Site C0004 (proposed Site NT2-01I) targeted the uppermost $400 \mathrm{~m}$ at the seaward edge of the Kumano Basin uplift (outerarc high) where the megasplay fault system branches and approaches the surface. This site penetrated the toe of a thrust wedge in the hanging wall of the megasplay fault system. The scientific objectives of drilling into the shallow portion of the megasplay fault were as follows:

1. Clarify the character and behavior of the shallow portion of the megasplay.

2. Characterize the slip, deformation mechanisms, and evolution in the stable region seaward of the unstable seismogenic fault.

3. Investigate the relationship between fluid behavior, slip, and deformation along and adjacent to the megasplay fault zone.

Four lithologic units were defined at this site during Expedition 316 (Fig. F5). The uppermost unit (lithologic Unit I; 0-78.08 $\mathrm{m}$ core depth below seafloor [CSF]) is dominated by greenish gray silty clay with a substantial component of calcareous nannofossils (up to $\sim 25 \%$ ) and a lesser amount of siliceous biogenic debris (sponge spicules, diatoms, and radiolarians). Unit I is interpreted to have been deposited from the early Pleistocene to the late Pleistocene as a sediment blanket on the upper slope mainly by hemipelagic settling with minor volcanic ash and sand-silt input. An observed gradual increase in carbonate content upsection is consistent with greater carbonate dissolution at depth and implies that the unit was slowly uplifted to its present water depth of $2632 \mathrm{~m}$. At $78.08 \mathrm{~m}$ CSF, an angular unconformity separates Units I and II; this unconformity was predicted by seismic reflection and LWD data (Kinoshita et al., 2008) and manifests prominent mineralizations by pyrite and other minerals. A significant age 
gap is indicated by both paleomagnetic and nannofossil data. Below the unconformity, the age of Unit II (78.06-258.01 $\mathrm{m} \mathrm{CSF}$ ) ranges from late Pliocene to middle Pliocene. The uppermost part of Unit II strata (Subunit IIA) consists mainly of sedimentary breccia interpreted as a mass transport complex (MTC) with silty clay clasts that most likely result from deposition of slumps and mass wasting along an unstable slope. The dominant lithology in Subunit IIB is dark greenish gray silty clay. The low carbonate content of Unit II is consistent with deposition at much greater depths than its present setting, presumably near or below the calcite compensation depth.

Unit III is a middle Pliocene structurally bounded package that hosts the brittle deformation of the splay fault zone. A biostratigraphic age reversal across the boundary between Units II and III suggests that the lithologic change to slightly more calcitic and ash-bearing sediments corresponds to a fault contact. A larger age reversal is found at the lower boundary between Units III and IV at $307.52 \mathrm{~m}$ CSF. Shipboard sedimentological observations are not able to resolve whether this Pliocene fault-bounded sedimentary package is more closely related to the overlying slightly older Pliocene prism sediments or the underlying slope basin sediments. Unit IV (307.52 m CSF to the bottom of Hole C0004D at $403 \mathrm{~m}$ CSF) is early Pleistocene in age and consists of dark olive-gray silty clay with a moderate amount of calcareous nannofossils and a lesser amount of calcareous and siliceous microfossils. Thin sand and silt beds are common in this unit, particularly in the upper part. It is interpreted to have formed in a lower trench-slope basin, dominated by fine-grained hemipelagic deposition with relatively minor sand input.

Structural observation of the upper slope sediments (Unit I) indicates southeast-dipping beds and normal faults (Fig. F5). Between 100 and 256 m CSF, faults and deformation bands are locally observed within the fragments of drilling-induced breccias, indicating deformation within the accretionary prism. In addition, sediment-filled veins (vein structures) are observed within the fragments, although these are rare. In most cases, faults cut and offset shear zones and have a reverse sense of shear with their displacement less than a few millimeters. A $\sim 60 \mathrm{~m}$ thick fractured and brecciated zone is observed between 256 and $316 \mathrm{~m} \mathrm{CSF}$; this zone contains two age reversals identified by biostratigraphy. The upper boundary is marked by the abrupt occurrence of brecciated fragments with polished and slickenlined surfaces below $256 \mathrm{~m}$ CSF. The lower termination of this zone was defined at $316 \mathrm{~m}$ CSF based on a gradual increase of unbroken rock intervals in which subhorizontal bedding and fissility are well preserved.
The seismic reflection profile suggests that the projected depth of the splay fault is $\sim 290 \mathrm{mbsf}$. Based on recovered cores, fractured rocks and drilling-induced breccias are widely distributed in the fault zone, whereas fault breccia and microbreccia have relatively limited distribution. At $291 \mathrm{~m} \mathrm{CSF}$, a $6 \mathrm{~cm}$ thick microbreccia is bounded above and below by fault breccia $\sim 50 \mathrm{~cm}$ thick, which in turn is bounded above and below by fractured rocks. The localized comminution in microbreccia zones contrasts with distributed deformation in fractured rocks and fault breccia. There is no obvious evidence of fluid-rock interaction (e.g., mineralized veins or alteration) in the fault zone. Microbreccia possibly represents a zone of concentrated shear within the splay faultrelated zone. However, the location of microbrecciation does not correlate with the two inversions of biostratigraphic age. The borehole image analysis of the structurally defined fault zone (depth shifted between Holes C0004B and C0004D) shows that electrically conductive fractures are relatively highly concentrated in these intervals. The presence of conductive fractures and/or highly deformed material associated with the concentrated shear may have caused the poor recovery within these intervals. The underthrust slope basin sediments show horizontal to gently dipping bedding and fissility, which is consistent with the bedding dips acquired by the borehole images at this site during Expedition 314 and the seismic reflection profile. Steeply dipping faults are sporadically distributed in the underthrust sediments; their random orientations suggest a lack of tectonic influence associated with plate convergence.

Shipboard measurements indicate that porosity decreases slightly, from $\sim 65 \%$ at the seafloor to $59 \%$ at $78 \mathrm{~m}$ CSF (Fig. F5). A discontinuity in porosity at $\sim 78 \mathrm{~m}$ CSF is related to the unconformity between the younger less compacted slope sediments and the older more compacted Pliocene prism sediments. Within Unit II, porosity slowly decreases with depth, from $\sim 53 \%$ at the top of Unit II to $\sim 49 \%$ near the bottom. Within Unit III, a region of faulted and brecciated sediments, porosity is scattered over the range 46\%-59\% with no clear trend. These perhaps higherthan-expected porosity values may be due to its younger age compared to the lower half of Unit II or pervasive crack/damage porosity within the fault zone. At the thrust fault boundary between Units III and IV, porosity abruptly decreases from $\sim 50 \%$ to $43 \%$ despite the biostratigraphic evidence that the underlying sediments of Unit IV are significantly younger than those of Unit III.

Within the underthrust sediments, $P$-wave velocity anisotropy is consistent with dominantly vertical compaction (vertical minimum velocity and high 
maximum and intermediate velocities within the bedding plane). However, anisotropy data could also be consistent with bed-parallel shear of the underthrust sediments. Electrical conductivity data appear to correlate with $P$-wave velocity data.

The average thermal conductivity values are 1.02 , 1.09 , and $1.50 \mathrm{~W} /(\mathrm{m} \cdot \mathrm{K})$, for Units I, II, and IV, respectively. In situ temperature was measured at four depths between 25.4 and $135.0 \mathrm{~m}$ CSF. Equilibrium temperatures plotted as a function of depth are relatively linear and, coupled with the average bottom water temperature, give a least-squares gradient of $52^{\circ} \mathrm{C} / \mathrm{km}$. A constant conductive heat flow appears to describe the overall thermal structure quite well.

Natural remanent magnetization (NRM) intensity spans more than two orders of magnitude, ranging from 0.02 to $80 \mathrm{~mA} / \mathrm{m}$. NRM intensity peaks at $352.7 \mathrm{~m} \mathrm{CSF}$, corresponding to silty clay with interbedded volcanic sand. Magnetic susceptibility values are generally $\sim 10 \times 10^{-3}$ SI within Units I-III and rapidly decrease and then increase within the breccia observed in Subunit IIA (Fig. F5). These susceptibility variations were verified by further measurements of corresponding discrete samples. Magnetic susceptibility is significantly higher within the underthrust slope deposits of Unit IV, which contain sand and silt layers, than it is in Unit III.

Pore fluid profiles in the upper $30 \mathrm{~m}$ of the sediment column are dominated by microbially mediated reactions, and the sulfate-methane transition (SMT) is reached between 16 and $20 \mathrm{~m}$ CSF. Below this depth, downhole increases in $\mathrm{Cl}, \mathrm{Na}$, and $\mathrm{H}_{4} \mathrm{SiO}_{4}$ concentrations and decreases in $\mathrm{Mg}, \mathrm{B}, \mathrm{K}$, and $\mathrm{Rb}$ concentrations are interpreted to be caused by alteration of volcanic ash to authigenic clay minerals and zeolites (Fig. F5). Sharp increases in $\mathrm{H}_{4} \mathrm{SiO}_{4}$, ammonium, and Mn concentrations, as well as decreases in $\mathrm{Mg}, \mathrm{K}$, and $\mathrm{Rb}$ concentrations, are observed $\sim 8 \mathrm{~m}$ above, within, and $29 \mathrm{~m}$ below the structurally identified splay fault zone. A decrease in $\mathrm{K}$ and $\mathrm{Mg}$ data is also evident at $50 \mathrm{~m}$ CSF. Given the reactive nature of these ions in pore fluids, these spikes may be caused by diagenesis; postcruise research will examine whether these are diagenetic signatures or related to fluid flow. Methane shows spikes of elevated concentration within Unit III and near the top of Unit IV (Fig. F5); however, core recovery and brecciation may greatly influence observed measured methane concentrations.

Under epifluorescent microscopy, very high numbers of microbial cells were observed in core sediments at Site C0004 (Fig. F5). Cell populations slightly decreased with depth to $150 \mathrm{~m}$ CSF and slightly increased at $\sim 280 \mathrm{~m}$ CSF in the splay fault zone. Cell populations then sharply decreased below the splay fault zone.

\section{Site $\mathrm{C0006}$}

Site C0006 (proposed Site NT1-03B) targeted the main frontal thrust at the seaward edge of the accretionary prism (Fig. F3). The scientific objectives of drilling at Site C0006 were as follows:

1. Clarify the evolution of the frontal thrust from its birth to death.

2. Clarify the function of the frontal thrust with respect to large earthquakes.

3. Evaluate the relationship between fluid behavior, slip, and deformation within this fault zone.

Site C0006 was previously drilled during Expedition 314 (Kinoshita et al., 2008), in which LWD logs were obtained to $885.5 \mathrm{~m}$ LWD depth below seafloor (LSF). During Expedition 316, coring was completed to $603 \mathrm{~m}$ CSF. Poor hole conditions stopped drilling at this site before the frontal thrust was reached.

Three lithologic units were recognized during examination of Site C0006 cores (Fig. F6). Unit I is Pleistocene-Holocene in age and extends from the seafloor to $27.23 \mathrm{~m}$ CSF. Unit I consists of a fining-upward succession of silty clay, sand, silty sand, and rare volcanic ash layers. Deposition is interpreted to have occurred on the lowermost slope above the trench floor by hemipelagic settling, turbidite deposition that decreased through time, and accumulation of a thick ash near the base of Unit I.

Unit II (27.23-449.67 m CSF) is Pleistocene in age and is interpreted as having been deposited in a trench setting, with increasing proximity to the axial portion of the trench upsection. Subunit IIA (27.23$72.06 \mathrm{~m} \mathrm{CSF}$ ) is dark gray to black fine-grained sand, consisting dominantly of metamorphic and volcanic lithic fragments with secondary quartz and feldspar. Individual sand beds ( 1-7 m thick) typically grade into silt and sometimes silty clay with indistinct boundaries between the different lithologies. Subunit IIB (72.06-163.33 m CSF) consists of interbedded fine-grained sand, silty sand, and silty clay in approximately equal abundances. Poor core recovery may indicate substantial loss of the sand units indicated by LWD logs (Kinoshita et al., 2008). Sand layers are typically normally graded with indistinct upper boundaries that grade into silty clay. The silty clay is greenish gray and is only slightly bioturbated or mottled in places. An age repetition zone within Zone NN19 was identified at the lithologic Subunit IIB/IIC boundary and is probably caused by faulting or affected by the presence of large amounts of reworked fossils. The dominant lithology in Subunit IIC (163.33-391.33 m CSF) is greenish gray silty clay, 
and minor lithologies include normally graded silt, sand, and rare ash. Of the siliciclastic beds, silt is generally more abundant than sand, particularly when compared to Subunit IIA. The dominant lithology of Subunit IID (391.33-449.67 m CSF) is greenish gray silty clay, and minor lithologies include silt and ash. Silt layers are thin-bedded and are relatively rare in this section, becoming absent below $405 \mathrm{~m}$ CSF. Sand is completely absent from this subunit, and ash layers are relatively abundant in comparison with overlying units. A short age gap ( 0.17 m.y.) was found between 434.71 and $439.50 \mathrm{~m}$ CSF. A longer age gap or unconformity ( 1 m.y.) was found at the Unit II/III boundary.

Unit III is late Miocene-early Pliocene in age and consists of greenish gray to grayish silty clay with some interbedded volcanic ash, including dolomiteand calcite-cemented ash. Unit III has an overall increased clay content and decreased quartz and feldspar contents compared to the overlying sediments. Unit III was deposited by hemipelagic settling along with accumulation of volcanic ash. The Mioceneearly Pliocene age and lithologic content of Unit III are similar to the Shikoku Basin facies documented at ODP Sites 1173 and 1174 in the Muroto transect more than $100 \mathrm{~km}$ to the west-southwest along the Nankai Trough (Shipboard Scientific Party, 2001a, 2001b; Moore et al., 2001).

Structural geology observations indicate that most bedding surfaces in Unit I strike north-south to northwest-southeast and dip westward. Between 15 and $35 \mathrm{~m} \mathrm{CSF}$, these sediments are affected by normal faults striking north-south to northwestsoutheast and dipping steeply with offsets $<10 \mathrm{~cm}$. The strikes of bedding or fissility surfaces in the accretionary prism sediments (below $27 \mathrm{~m} \mathrm{CSF}$ ) are variable, and no preferred direction is apparent. Between 28 and $31 \mathrm{~m} \mathrm{CSF}$, sediments are cut by two reverse faults showing very small offsets $(<1 \mathrm{~cm})$.

A broad fractured/brecciated zone extends from 230 to $545 \mathrm{~m}$ CSF (Fig. F6). In this zone, cores are commonly strongly fractured, striated or polished planes are common, and tectonic breccias were identified. In contrast, the sections above or below this fractured and brecciated interval are more coherent and less fractured and generally do not include tectonic breccias. The transition between the fractured/brecciated zone and the underlying sections appears to be sharp. Deformation bands are observed in cores between 300 and $460 \mathrm{~m} \mathrm{CSF}$ with a clear predominance between 300 and $405 \mathrm{~m}$ CSF. Within this section, most deformation bands dip $>30^{\circ}$ and the sense of shear is reverse. These bands predominantly strike about northeast-southwest and dip either northeastward or southwestward, forming two sets with an apparent conjugate geometry. Given the reverse sense of slip observed along these deformation bands, this geometry suggests a shortening axis that is horizontal and oriented along $138^{\circ}$.

Concentrated deformation zones occur at 235-243, 277-297, 367.5-369.5, 433.75-440, and 533-543 m CSF (Fig. F6). These zones contain greater densities of deformation bands, fractures, and tectonic breccias. The lowermost interval (533-543 m CSF) contains a progression from tectonic breccia to microbreccia and then fault gouge. The sediments recovered in the 545-603 m CSF interval, which consist of bioturbated hemipelagic mud (Unit III), are less fractured or brecciated than observed above. Normal faults predominate in this interval; dip angles of fault planes are scattered between $20^{\circ}$ and $88^{\circ}$, but steep angles predominate. No preferred orientation of fault plane directions is recognized.

A notable feature of the porosity profile at Site C0006 is that near-surface ( $>5 \mathrm{~m} \mathrm{CSF}$ ) porosity values are quite low, averaging $\sim 48 \%$ (Fig. F6); this suggests the possibility of erosion of overlying material. From $\sim 5$ to 410 m CSF, porosity gradually decreases with depth from $\sim 48 \%$ to $\sim 38 \%$. Between $\sim 410$ and $\sim 450$ m CSF, porosity increases from $\sim 39 \%$ to $\sim 49 \%$; the highest porosity values $(\sim 50 \%)$ are between $\sim 450$ and $490 \mathrm{~m}$ CSF. This interval includes a deformation zone at $433.75-440 \mathrm{~m} \mathrm{CSF}$, raising the possibility that elevated porosity results from microcracks and other fault-related damage within the samples or that sediments in this zone are underconsolidated because of elevated fluid pressures. The observed increase in porosity is also coincident with an increase in clay content, which could contribute to low permeabilities and encourage undercompaction. Alternatively, if the clay contains interlayer water, the apparent porosity change could partially reflect interlayer water that cannot be distinguished from pore water in the moisture and density (MAD) measurements. Porosity values that are corrected postcruise to account for hydrous clay content will shed light on this possibility. From $\sim 475$ to $570 \mathrm{~m} \mathrm{CSF}$, porosity decreases from $\sim 49 \%$ to $\sim 40 \%$, reaching values at $570 \mathrm{~m}$ CSF that are in good agreement with the extrapolated porosity trend observed from 5 to $\sim 410 \mathrm{~m} \mathrm{CSF}$.

Electrical conductivity exhibits an overall decrease with depth but increases at $\sim 410 \mathrm{~m}$ CSF, mimicking the change in porosity. Electrical conductivity anisotropy values show considerable scatter at depths shallower than 300 m CSF; between 300 and $400 \mathrm{~m} \mathrm{CSF}$, the transverse anisotropy decreases with depth. This observation, coupled with the decrease of electrical conductivity magnitude, suggests progressive horizontal compaction. $P$-wave velocity generally increases with depth through the hole. The 
anisotropy of $P$-wave velocity data show a general decrease with depth with two discrete zones of higher transverse anisotropy at $\sim 400$ and $\sim 480$ m CSF.

Vane shear measurements of shear strength increase rapidly through the uppermost $40 \mathrm{~m}$ CSF, below which measured shear strength drops rapidly and is associated with the prevalence of sandy beds, where the measurement technique might not be suitable. The boundary between Subunits IIA and IIB is coincident with an increase in shear strength at $72 \mathrm{~m}$ CSF. A similar increase at $110 \mathrm{~m}$ CSF does not appear to be concurrent with a significant lithologic change. Shear strength continues to increase to $200 \mathrm{~m}$ CSF. Between 200 and $275 \mathrm{~m}$ CSF there is an apparent decrease in shear strength.

Thermal conductivity from the seafloor to $\sim 80 \mathrm{~m}$ CSF shows a striking positive excursion through Unit I and Subunit IIA that likely reflects higher sand content through this interval. A negative trend in thermal conductivity through Subunit IIA likely reflects a decrease in sand content. Between $\sim 80$ and $400 \mathrm{~m}$ CSF, thermal conductivity values generally increase and likely reflect decreasing porosity. Thermal conductivity in Unit III increases with depth but is offset to lower values relative to the trend through Subunits IIB and IIC. In situ temperature was measured using both the advanced piston coring temperature tool (APCT3) and the Davis-Villinger Temperature Probe (DVTP). The best fitting thermal gradient through the first six measurements is $27^{\circ} \mathrm{C} / \mathrm{km}$. This very low thermal gradient gives rise to an anomalously low heat flow value.

Paleomagnetic measurements indicate that the mud in Unit III has the lowest NRM intensity (averaging $\sim 0.1 \mathrm{~mA} / \mathrm{m})$ compared to turbiditic Unit II $(\sim 12 \mathrm{~mA} / \mathrm{m})$ and the nannofossil-bearing mud and sand of Unit I $(\sim 2 \mathrm{~mA} / \mathrm{m})$. Variations in magnetic susceptibility generally parallel variations in NRM intensity. Magnetic susceptibility values are generally $\sim 19 \times 10^{-3} \mathrm{SI}$ for sediments in Unit I, $>200 \times 10^{-3}$ SI for Unit II, and $12 \times 10^{-3}$ SI for Unit III (Fig. F6). A few discrete peaks of higher NRM and susceptibility values appear at some depth intervals in Units I and II and can be tied directly to the visible presence of volcanic sand in these regions.

Pore fluid profiles in the upper $\sim 60 \mathrm{~m}$ of the sediment column are dominated by microbially mediated reactions, and the SMT is reached at 8-12 m CSF. The relatively shallow SMT at this site suggests an elevated upward methane flux; coupled with anomalously low heat flow, this flux provides ideal conditions for gas hydrate formation in the sediment. Assuming equilibrium with Structure I gas hydrate, the gas hydrate stability field extends from the seafloor to $~ 800-850$ mbsf. Dissociation of disseminated gas hydrates within the sediment pore space during recovery is suggested by pore fluid $\mathrm{Cl}$ concentration that gradually declines from 571 to $540 \mathrm{mM}$ at depths of $~ 100-500 \mathrm{~m} \mathrm{CSF}$ (Fig. F6). Assuming that all the hydrate dissociates during core recovery and handling, the gradual decrease in pore fluid $\mathrm{Cl}$ with depth indicates that gas hydrate concentrations, though overall very low (negligible to $<2 \%$ ), increase with depth. Superimposed on the gradual decline in $\mathrm{Cl}$ concentration are three $\mathrm{Cl}$ minima at 76,292 , and $570 \mathrm{~m}$ CSF that indicate horizons of elevated gas hydrate occurrence; however, the concentration at these depths are still relatively low, comprising less than $\sim 5 \%$ of the sediment pore space.

Pore fluid geochemical profiles are relatively smooth through the deformation zone at Site C0006 (Fig. F6). No local maxima or minima are coincident with the faults described at Site C0006. Thus, pore water chemistry provides no indication of fluid flow along these fault zones. From $\sim 450 \mathrm{~m}$ CSF to the base of the hole at $\sim 600 \mathrm{~m}$ CSF, many of the pore fluid chemical profiles (e.g., $\mathrm{Mg}, \mathrm{Ca}, \mathrm{Li}, \mathrm{K}, \mathrm{Rb}, \mathrm{Cs}, \mathrm{B}$, and $\mathrm{Mn}$ ) change distinctly. These geochemical variations could reflect diagenetic reactions because of the higher clay content or greater age of pore fluids in the Miocene sediments of Unit III. Another possibility is that these fluids reflect communication with a fluid originating deeper than the base of Hole C0006F.

The depth profile of methane below $14 \mathrm{~m}$ CSF decreases throughout the sediment column, except for two peaks at 100 and $310 \mathrm{~m} \mathrm{CSF}$ (Fig. F6). These increased methane values could be related to the destabilization of gas hydrates and the consequent release of methane into the sediment. Ethane was detected in low amounts in sediment at depths below $76 \mathrm{~m}$ CSF. Higher molecular weight hydrocarbons were not detected at Site C0006. Except for a few enrichments, total organic carbon (TOC) remains low throughout the core (average $=0.46 \mathrm{wt} \%$ ). Total nitrogen $(\mathrm{TN})$ is highest in Unit III, perhaps because of clay-bound nitrogen substances. The ratio of TOC and TN $(\mathrm{C} / \mathrm{N})$ averages $\sim 7.0$, indicating that the organic matter at Site C0006 is mainly of marine origin. The concentration of total sulfur (TS) in the sediments is generally low with a mean value of $0.25 \mathrm{wt} \%$.

Preliminary microbial cell abundances were enumerated by visual inspection (Fig. F6). At Site C0006, $\sim 10^{9}$ cells $/ \mathrm{cm}^{3}$ were detected in the upper sedimentary unit above $100 \mathrm{~m}$ CSF. The porous sand layers in the upper unit harbor abundant microbial populations, suggesting that the environment is rich in available energy sources and habitable space. The potential energy sources in the sand layers are probably buried consumable organic matter (e.g., organic 
acids). Below the upper sedimentary unit, the population decreased with increasing depth in the accretionary prism with no or very small proliferation of cell abundance observed at sand layers or lithologic boundaries. Generally, the microbial population in the accretionary prism at Site C0006 was found to be low $\left(10^{7}\right.$ cells $\left./ \mathrm{cm}^{3}\right)$, suggesting that this accretionary prism may be a harsh and energy-starved habitat for subseafloor life. This is in clear contrast to the accretionary prism at Site C0004, where relatively high biomass is present throughout the cored materials.

\section{Site $\mathbf{C 0 0 0 7}$}

Site C0007 (proposed Site NT1-03A) targeted the main frontal thrust at the seaward edge of the accretionary prism (Fig. F3). This site was drilled during Expedition 316 after hole conditions at Site C0006 precluded reaching the frontal thrust.

Four lithologic units were identified at Site C0007 (Fig. F7). The uppermost unit (lithologic Unit I; 0$33.94 \mathrm{~m}$ CSF) consists of hemipelagic silty clay with interbedded sand. Deposition of this unit is interpreted to have occurred on the lowermost slope above the trench floor by hemipelagic settling, turbidite deposition, and possibly subsequent softsediment slumping on an oversteepened slope.

The top of Unit II is placed at the first occurrence of a thick interval of dark sand. Unit II (33.94-362.26 m CSF) constitutes a coarsening-upward succession from fine-grained mud to sand- and gravel-rich deposits. Unit II is interpreted to have been deposited in a trench setting with increasing proximity to the axial portion of the trench upsection. Repetition of coarser facies, interpreted as axial-channel fill, indicates (1) a repetition of the sequence because of thrust faulting, (2) switching of the position of the trench channel because of advancement of the thrust front, or (3) major slumping of the rapidly steepened frontal slope. Biostratigraphy suggests a possible age reversal below 135 mbsf in Hole C0007C (within Unit II) and a significant age gap between Units II and III.

Unit III (362.26-439.44 m CSF) is a Pliocene succession of green bioturbated fine-grained hemipelagic sediments. Thin $(<1 \mathrm{~cm})$ greenish layers, reworked glauconite, and pervasive burrowing suggest that low sedimentation rates attended the deposition of this lowermost mud. Small ash layers and dispersed ash made of clear glass and pumice are observed throughout the section but are especially abundant within the lowermost portion of Unit II and in Unit III. Unit III was deposited by hemipelagic settling with accumulation of volcanic ash; its age and characteristics are similar to the Shikoku Basin facies as documented in the western Nankai Trough (Shipboard Scientific Party, 2001a, 2001b).

Unit IV is of possible Pleistocene age based on its correlation on seismic profiles with the active trench wedge of the Nankai Trough to the southwest of Site C0007. Only $25 \mathrm{~cm}$ of dark gray sand and a few drillingaffected mud fragments were recovered. The presence of thick unconsolidated sand is also suggested by the significant increase in drilling penetration rate below $439 \mathrm{~m}$ CSF. The sand is fine to medium grained and consists of abundant black lithic fragments, metamorphic rock fragments, ferromagnesian minerals, quartz, feldspar, and opaque grains. Nannofossil dating of Unit IV was not possible, as recovered sediments were either potential fall-in material or a sand slurry that did not yield nannofossils.

Structural geology observations describe slumprelated features (e.g., disaggregated or chaotically mixed bedding) in the upper portion of Hole C0007C. Bedding dips between $20^{\circ}$ and $70^{\circ}$ to the southeast in Unit I, which is in contrast to gently dipping beds in the prism below (Fig. F7). In places, faults offset bedding with normal or reverse sense of shear and displacement of less than a few centimeters, and faults show scattered orientations after paleomagnetic correction. Sandy layers are locally disturbed and form inclusions in the muddy matrix, or in the extreme case, sandy layers are chaotically mixed with the muddy layers.

Bedding and fissility dip gently $\left(0^{\circ}-30^{\circ}\right)$ throughout Site $\mathrm{C0007}$ prism sediments. Bedding-oblique deformation bands show a conjugate geometry of reverse slip associated with northwest-directed layer-parallel contraction. Two types of healed faults are observed in bioturbated hemipelagic mud: a parallel to bedding type and a type defined by randomly oriented normal faults.

Three fault zones were recognized in cores recovered from Hole C0007D. A fault zone at 237.5-259.3 m CSF (fault Zone 1) is related to a thrust that brings mud onto sand. Fault breccias in this fault zone are $17-19 \mathrm{~cm}$ thick and are characterized by $1-10 \mathrm{~mm}$ sized angular to subangular fragments. The brecciated fragments are commonly polished and slickenlined and lineations indicate multiple slip directions. Occurrence of three similar ash layers in this fault zone could indicate repetition of the same layer by thrust faulting; this possibility needs to be confirmed by postcruise research.

A fault zone at 341.5-362.3 m CSF (fault Zone 2) is located where the lithology changes from mud (Unit II) to bioturbated hemipelagic mud (Unit III). The location of this zone is comparable to the interval where a subhorizontal strong reflector is recognized 
in a nearby seismic line (Fig. F3) and an age gap is noted by the biostratigraphy. This fault zone consists mostly of fractured rocks characterized by fragmentation along sets of polished and striated surfaces. Concentration of deformation at the bottom of the fault zone is indicated by occurrence of breccia and fault gouge. Fault breccia includes subangular to rounded fragments of $\sim 1 \mathrm{~mm}$ to $2 \mathrm{~cm}$ in size and a random texture. Fault breccia is replaced by fault gouge at $362.1 \mathrm{~m}$ CSF. This is marked by a decrease in size and volume fraction of fragments to $<2 \mathrm{~mm}$ and 30\%, respectively. Fault gouge is weakly foliated and the angle between a foliation defined by alignment of fragments and the horizontal plane is $38^{\circ}$. Deformation bands are concentrated above fault Zone 2 and band kinematics show reverse slip associated with northwest-directed contraction. Deformation bands are absent below fault Zone 2, but healed faults are well developed and show normal slip consistent with vertical compaction of sediments during burial. The changes in deformation style and kinematics of structures across the fault zone, as well as the asymmetric distribution of fractured rock, suggest that the major slip zone is located at the bottom of the fault zone, possibly represented by the fault breccia/fault gouge zone.

Fault Zone 3 is located at the basal part of the prism above the frontal thrust that juxtaposes the hemipelagic mud (Unit III) above and sand-dominated sediments (Unit IV) below. This zone is marked by a heterogeneous distribution of fractures, commonly with polished and slickenlined surfaces and brecciation. A foliated fault gouge was observed at 418.83$418.94 \mathrm{~m}$ CSF with a shear sense consistent with thrust faulting. The lowermost part of the fault zone at $438.28-438.57 \mathrm{~m}$ CSF is intensely brecciated into fragments $\sim 1-10 \mathrm{~mm}$ in size. This $29 \mathrm{~cm}$ thick breccia shows a foliated aspect from an anastomosing network of polished and striated surfaces. At the base of this zone, a $2 \mathrm{~mm}$ thick dark layer sharply separates intensely brecciated hemipelagic mud above from unbroken hemipelagic mud and ash below. There is a biostratigraphic age reversal across the lowermost part of the fault zone (Fig. F7). These features indicate that the thin dark layer most likely represents extreme localization of slip associated with thrust faulting. Below this interval recovery was poor; however, additional thrust faulting is inferred from the transition to unconsolidated axial trench deposits (Unit IV).

Porosity decreases rapidly in the uppermost $34 \mathrm{~m}$ at this site (Fig. F7). From 34 to 320 m CSF, porosity decreases more gradually from $\sim 48 \%$ to $\sim 39 \%$ at $320 \mathrm{~m}$ CSF, increases from $\sim 39 \%$ to $\sim 50 \%$ at $400 \mathrm{~m} \mathrm{CSF}$, and then decreases to the bottom of the hole. Porosity data reveal no clear discontinuities at depths corresponding to possible faults or at lithologic boundaries within that depth range. The zone of highest porosity ( $50 \%)$ between $\sim 360$ and $\sim 400 \mathrm{~m}$ CSF overlies fault Zone 3. Lithologic analyses reveal that Unit III exhibits an overall increase in clay content, which could lead to spuriously high values of porosity because the drying process during MAD analysis removes interlayer water from smectite. Alternatively, elevated porosity in this zone could indicate microcracks and other fault-related damage or that these sediments are underconsolidated (and therefore overpressured), which may have localized shear deformation in this interval and would be consistent with the probable lower permeability associated with higher clay contents. Clays may also decrease permeability of the sediments/rocks in this interval, leading to overpressurization of pore fluids.

$P$-wave velocity values of discrete samples range between 1800 and $2000 \mathrm{~m} / \mathrm{s}$. Velocity generally increases to $360 \mathrm{~m} \mathrm{CSF}$ (Unit II/III boundary) and then decreases to $\sim 440 \mathrm{~m}$ CSF. It is possible that the apparent decrease below $360 \mathrm{~m} \mathrm{CSF}$ is the combination of a $P$-wave velocity offset (about $-100 \mathrm{~m} / \mathrm{s}$ ) because of lithologic changes or thrust faults observed at $\sim 430$ $440 \mathrm{~m}$ CSF. Electrical conductivity data appear to be inversely correlated to $P$-wave velocity data. Shear strength increases rapidly from the seafloor to $35 \mathrm{~m}$ CSF. Shear strength through this interval increases at a much faster rate than at similar depths at Sites C0004 and C0006. Below 35 m CSF, shear strength shows cycles of decreases and increases until it is too consolidated for measurement below $91 \mathrm{~m}$ CSF.

Thermal conductivity ranges from 0.94 to $1.58 \mathrm{~W} /$ $(\mathrm{m} \cdot \mathrm{K})$. Thermal conductivity increases rapidly from the seafloor to $\sim 50 \mathrm{~m} \mathrm{CSF}$, likely reflecting the decrease in porosity with depth and relatively high sand content. A negative trend in thermal conductivity occurs between $\sim 50$ and 75 m CSF, likely reflecting a decrease in sand content. Between $\sim 80$ and $400 \mathrm{~m}$ CSF, thermal conductivity values fall within a restricted range of values between 1.2 and $1.4 \mathrm{~W} /$ $(\mathrm{m} \cdot \mathrm{K})$. In situ temperature was measured using the both the APCT3 and sediment temperature tool. The average apparent bottom water temperature is $1.65^{\circ} \mathrm{C}$. Equilibrium temperatures as a function of depth are quite linear. The best fitting thermal gradient through the first six measurements is $42^{\circ} \mathrm{C} / \mathrm{km}$. The least-squares fit to the temperature as a function of thermal resistance indicates a heat flow of 53 $\mathrm{mW} / \mathrm{m}^{2}$ and a bottom water temperature of $2.0^{\circ} \mathrm{C}$. The computed heat flow is anomalously low with respect to other values of heat flow in the vicinity of the Kii transect (Yamano et al., 2003), although it is higher than measured at Site C0006. 
In the nannofossil-bearing mud and sand cores in Unit I, both the intensity of NRM and magnetic susceptibility increase steadily downhole (Fig. F7). Numerous volcanic ash and sand layers in Unit II have relatively high concentrations of magnetic minerals, causing relatively high NRM intensity (average $15 \mathrm{~mA} / \mathrm{m})$ and magnetic susceptibility $\left(\sim 190 \times 10^{-3}\right.$ SI units). The mud of Unit III has the lowest NRM intensity (mean $\sim 0.25 \mathrm{~mA} / \mathrm{m}$ ) and magnetic susceptibility (mean $\sim 9 \times 10^{-3}$ SI units) at Site C0007. Poor recovery of underthrust trench wedge type sand and rocks in Unit IV limits paleomagnetic work, although a few pass-through magnetic susceptibility measurements indicate relatively high susceptibility values.

Pore water analyses indicate that sulfate reduction is relatively rapid in the upper $\sim 20 \mathrm{~m}$ of the sediment section of Hole C0007C; however, sulfate never reaches depletion and remains $\sim 8-14 \mathrm{mM}$ to the bottom of the hole. In Hole C0007D, sulfate was totally depleted at the start of coring (175 m CSF) with only localized horizons of elevated sulfate. In Hole C0007D, there is evidence of gas hydrate occurrence at $\sim 325 \mathrm{~m}$ CSF where $\mathrm{Cl}$ values are $\sim 10 \%$ less than modern seawater and dilution is also observed in the other major ions (Fig. F7).

Within Unit III, $\mathrm{Ca}, \mathrm{H}_{4} \mathrm{SiO}_{4}, \mathrm{Li}$, and $\mathrm{Mn}$ concentrations increase and $\mathrm{Cl}$, alkalinity, $\mathrm{Ba}, \mathrm{K}$, and $\mathrm{B}$ concentrations decrease. The maxima and minima coincide with the deepest of three fault zones observed in cores from this site (400-420 m CSF). Pore fluid concentration reverses below 420 mbsf in the lowermost 1-3 samples at this site. Pore water chemical changes within Unit III could result from diagenetic changes associated with sediment composition or reflect communication with fluid of a different composition below.

In Hole C0007C, methane concentration increases with depth but remains low $(<50 \mu \mathrm{M})$. Methane concentration increases from the beginning of coring at $175 \mathrm{~m}$ CSF to a maximum of $5.3 \mathrm{mM}$ at $\sim 230 \mathrm{~m} \mathrm{CSF}$ and decreases below $230 \mathrm{~m}$ CSF (Fig. F7). Further light hydrocarbons were only detected in one sample in Hole C0007C, and ethane is very low in Hole C0007D. The methane to ethane ratio indicates a biogenic origin. The amount of calcite is generally very low; the highest values in Hole C0007C (up to $\sim 5 \mathrm{wt} \%)$ are observed in Unit I sediments and at $\sim 82 \mathrm{~m}$ CSF. At this depth, the highest TOC content $(\sim 0.7 \mathrm{wt} \%)$ was found for this site. A slight enrichment of TS was found in Unit I at $\sim 6$ m CSF. In Hole C0007D, calcite concentration increases with depth and shows higher amounts below $300 \mathrm{~m}$ CSF. The TOC content remains low throughout the sediment column and the $\mathrm{C} / \mathrm{N}$ ratio indicates marine origin of the organic matter. Except for a peak at $\sim 190 \mathrm{~m} \mathrm{CSF}$, TS is low and only increases slightly below $\sim 360 \mathrm{~m}$ CSF in Unit III.

Based on fluorescent microscopic observation, the sediments at Site C0007 consistently harbor $\sim 10^{8}$ cells $/ \mathrm{cm}^{3}$ (Fig. F7). In the sand layers of the upper sedimentary units, very bright fluorescent signals of SYBR Green I-stained cells were observed, indicating that metabolic activities of microbes are generally high.

\section{Site $\mathrm{C0008}$}

Site C0008 was proposed as contingency Site NT2$10 \mathrm{~A}$ in an addendum to the Expedition 316 Scientific Prospectus (Kimura et al., 2007b). This site examined the basin seaward of the splay fault penetrated at Site C0004. Site C0008 is located $\sim 1 \mathrm{~km}$ seaward of Site C0004 (Fig. F4). This site was selected during Expedition 316 because of its good fit within the available time window and the scientific objectives of Expedition 316. Recovered material from this basin will help assess the timing and relative age of past fault motions via identification of provenance and age of basin material. Ages across any unconformities between newly deposited sediments and older uplifted fault blocks will constrain the deformation history. The basin material will provide reference properties for the section overrun by the splay fault. Shipboard and shore-based study of these properties will constrain the fluid flow and consolidation response of the footwall to splay fault movement. In situ temperature measurements were also collected to assess the thermal gradient and heat flow in this area for comparison with the temperatures recorded at Site C0004.

Two lithologic units were identified at Site C0008 (Fig. F8). The uppermost unit (lithologic Unit I) consists of a $272 \mathrm{~m}$ (in Hole C0008A) succession of hemipelagic silty clay with thin sand beds and volcanic ash layers. In addition to the discrete ash layers, volcanic glass and pumice are disseminated as a significant component within the sediments. At the base of Unit I, a $40 \mathrm{~m}$ section of clayey gravel containing rounded clasts of mudstone and pumice constitutes Subunit IB. This subunit is interpreted as a MTC accumulated in the lower slope basin, possibly during an early stage of basin formation. The Pleistocene/Pliocene boundary is found within Subunit IB. Unit II includes $\sim 57 \mathrm{~m}$ of sand-rich sediment for which there was very limited recovery. This sand, along with a minor gravel component, contains a diverse detrital grain assemblage that includes clasts of sedimentary, metasedimentary, plutonic, and volcanic rocks.

Structural observations of the two holes drilled at Site C0008 indicate that sediments are nondeformed 
to weakly deformed. The main structural features consist of subhorizontal bedding and normal faults (Fig. F8). Deformation bands and sediment-filled veins were not observed. Normal faults do not show any preferred orientation, suggesting that they reflect vertical compaction. A high concentration of normal faults is found in Hole C0008C between 35 and $80 \mathrm{~m} \mathrm{CSF}$, and a $5 \mathrm{~cm}$ thick gently dipping shear zone was observed by computed tomography (CT) scan image analysis at $\sim 41 \mathrm{~m}$ CSF. These features could correspond to the discontinuity in bedding dip that is apparent in seismic reflection profiles.

Two microfossil groups, calcareous nannofossils and radiolarians, from core catcher samples were analyzed for biostratigraphy at Site C0008. Moderately preserved and abundant calcareous nannofossils and radiolarians were seen in samples from the upper part of the sequences in Holes C0008A and C0008C, whereas they are relatively poorly preserved in the lower part of the sequences in both holes. For sediments recovered in Hole C0008A, calcareous nannofossil zones from Pleistocene Zone NN21 to Pliocene Zone NN16 were recognized and Pleistocene radiolarian Botryostrobus aquilonaris and Encyrtidium matuyamai zones were determined. Between 11.92 and $21.31 \mathrm{~m} \mathrm{CSF}$, a transition from Zones NN21 to NN19 is observed, suggesting low sedimentation rates or an age gap. Both calcareous nannofossils and radiolarians suggest an age reversal at $\sim 90 \mathrm{~m}$ CSF; postcruise work will evaluate whether this reversal is an artifact of reworking. No reliable ages were obtained below $282.35 \mathrm{~m}$ CSF. A sample at $329.36 \mathrm{~m}$ CSF indicates a Miocene Zone NN11 age; however, because this was an isolated clast, it is not clear if this is representative of the formation.

Paleomagnetic studies in Hole C0008A indicate that $\mathrm{NRM}$ averages $10 \mathrm{~mA} / \mathrm{m}$ between 0 and $45 \mathrm{mbsf}$, $39 \mathrm{~mA} / \mathrm{m}$ between 40 and $150 \mathrm{mbsf}$, and $207 \mathrm{~mA} / \mathrm{m}$ between 160 and 270 mbsf. Magnetic susceptibility and NRM intensity variations through sedimentary units are closely correlated. Two sharp increases in magnetic susceptibility are present at $\sim 45$ and $165 \mathrm{~m}$ CSF. Interestingly, the stable inclinations also switch polarity from normal to reversed at $\sim 165 \mathrm{~m} \mathrm{CSF}$, suggesting that characteristic susceptibility and NRM intensity response might be useful for identifying geomagnetic event boundaries. Variations in magnetic susceptibility are probably caused by variations in the magnetic mineral type or in the content of magnetic minerals in the observed volcanic ashes and silty clay with depth. Parts of the magnetic polarity interval were able to be correlated with biostratigraphic data to refine the age history at the site.

In Hole C0008A, porosity from discrete samples decreases with depth from $\sim 65 \%$ at the surface to $50 \%$ at $270 \mathrm{~m} \mathrm{CSF}$ (Fig. F8). This is mirrored by an increasing trend of bulk density values. Bulk density increases with depth from $\sim 1.60 \mathrm{~g} / \mathrm{cm}^{3}$ at the surface to $\sim 1.87 \mathrm{~g} / \mathrm{cm}^{3}$ at $270 \mathrm{~m} \mathrm{CSF}$. Grain density is almost constant at $\sim 2.69 \mathrm{~g} / \mathrm{cm}^{3}$. Thermal conductivity values increase slightly with depth but are scattered because of gas expansion cracks in much of the core. Heat flow at Site C0008 is low compared to near-surface data but agrees well with heat flow at Site C0004. Heat flow estimates in Holes C0008A and C0008C yield similar results. Thermal conductivity values associated with Holes C0008A and C0008C vary between 0.7 and $1.2 \mathrm{~W} /(\mathrm{m} \cdot \mathrm{K})$ and show a great deal of scatter, possibly because of gas expansion cracks. In situ temperature was measured using the APCT3 in Holes C0008A and C0008C and supplemented by the sediment temperature tool in Hole C0008A. The best fitting thermal gradients are $51^{\circ} \mathrm{C} / \mathrm{km}$ and $57^{\circ} \mathrm{C} / \mathrm{km}$ in Holes C0008A and C0008C, respectively.

One of the main features in pore water chemical profiles at Site $\mathrm{C0008}$ is the evidence for gas hydrate occurrence. In Hole C0008A, gas hydrate is evidenced by two sharp and local $\mathrm{Cl}$ minima detected at $\sim 120$ and $136 \mathrm{~m} \mathrm{CSF}$, in which $\mathrm{Cl}$ values were $2 \%-3 \%$ less than modern seawater. These local minima coincide with concentration minima in $\mathrm{Na}, \mathrm{Sr}, \mathrm{PO}_{4}$, and salinity, and the minimum at $136 \mathrm{~m} \mathrm{CSF}$ is very near a maximum in methane concentration (at $\sim 140 \mathrm{~m}$ CSF). After thermal infrared camera scanning in the cutting area showed negative temperature anomalies, we were able to sample gas hydrate-bearing horizons in Hole C0008C. Hole C0008C shows seven pronounced negative $\mathrm{Cl}$ concentration excursions between $\sim 70$ and $170 \mathrm{~m}$ CSF. The lowest $\mathrm{Cl}$ concentration was observed at $149.8 \mathrm{~m}$ CSF and was half modern seawater values. These $\mathrm{Cl}$ anomalies are accompanied by minima in the concentration-depth profiles of other chemical species. These coincident anomalies were predominantly associated with ash or coarse sand layers and indicate horizons of high gas hydrate concentration in Hole C0008C.

Inorganic geochemical data suggest that the SMT is reached at 6-10 m CSF in Hole C0008A and between 4 and $6 \mathrm{~m}$ CSF in Hole C0008C. The SMT depth at this site is much shallower than the other sites drilled during Expedition 316. Methane concentration increases sharply from the SMT zone and reaches $8.5 \mathrm{mM}$ at $\sim 15.3 \mathrm{~m}$ CSF in Hole C0008A. Below this depth, methane decreases to $\sim 2 \mathrm{mM}$ at $60 \mathrm{~m}$ CSF and remains at this concentration to the base of the sediment column in Hole C0008A, except for a localized enrichment at $\sim 140 \mathrm{~m}$ CSF. At this depth, methane concentration reaches $15 \mathrm{mM}$, indicating the presence of gas hydrates. The $C_{1} / C_{2}$ ratio increases in the uppermost $15 \mathrm{~m}$ and then decreases to 
372 at $~ 160 \mathrm{~m} \mathrm{CSF}$, but no further light hydrocarbons were detected.

Calcium carbon content is relatively high in the upper $50 \mathrm{~m}$ (with concentration as high as $22.3 \mathrm{wt} \%$ ) and decreases in the lower portion of the site. Total carbon and $\mathrm{TN}$ concentration remains low throughout the site and shows a strong positive correlation. The $\mathrm{C} / \mathrm{N}$ ratio remains generally low, indicating marine origin of the organic matter. TS content is rather high in the upper $50 \mathrm{~m}$ and in the lower $\sim 60 \mathrm{~m}$ of the sediment column in Hole C0008A, correlating with the occurrence of iron sulfides.

Microorganisms inhabiting marine subsurface sediments play significant roles for biogeochemical cycling of one-carbon compounds, such as methane production and consumption. At Site C0008, more than $10^{8}$ cells $/ \mathrm{cm}^{3}$ were observed throughout the sediment cores from Holes C0008A and C0008C. Microbial communities are mainly composed of very small coccoids and short rods. Cell abundances in Hole C0008C were slightly higher than those in Hole C0008A, suggesting that the flux of nutrient and energy substrates, as well as the occurrence of methane hydrates, controls the population size and activities of subseafloor microbial life.

\section{Discussion}

As a result of the expedition, several unsolved questions were clarified although results and synthesis are still in a preliminary stage. We briefly discuss these preliminary results in this section.

\section{Activity of the megasplay fault}

Seismic and tsunami inversion studies combined with seismic reflection research strongly suggested that the splay fault system drilled at Site C0004 slipped during the 1944 Tonankai M 8.2 earthquake (Park et al., 2002) and generated a tsunami. Moore et al. (2007) also suggest recent historical and geological accumulation of displacement along the fault on the basis of 3-D seismic reflection investigation. Although various lines of evidence suggest relatively recent activity along the splay fault, there is one conflicting feature on the seismic profile. The splay fault clearly thrusts the hanging wall prism over younger slope sediments in the footwall; however, the youngest slope sediments that cover the fault appear not to be cut by the fault. In addition, the lack of a slope break on the seafloor above the fault could also suggest that this splay fault is presently not active but ceased activity in the recent past. However, shipboard results provide support for an alternate interpretation: the splay fault is active as a blind thrust in which the tip of the fault has not propagated to the surface but remains buried. Slip on deeper levels of the fault zone are expressed by some combination of folding and layer-parallel slip in the shallow slope sediments draping the uppermost portion of the megasplay, as well as the possible triggering of marine slump or slide deposits.

Drilling results at Site C0004 indicate that the shallowest cover sediments above the hanging wall wedge are composed of repeated MTCs associated with repeated slope collapses and rip-up debris generation. Pleistocene cover sediments dip steeply approximately parallel to the slope and are cut by numerous normal faults. Normal faults are also developed within the slope basin sediments in Holes C0008A and C0008C. These lines of evidence document that the slope is quite unstable and easily collapses when triggered, possibly by earthquakes. The age reversal from Pliocene to Pleistocene documented beneath the splay fault is also consistent with geologically recent activity.

Despite inferences of recent activity on the splay fault system, no porosity inversion is observed beneath the splay fault; this contrasts with previous results from the décollement of the Muroto transect (Screaton et al., 2002), in which a clear porosity inversion across the fault likely reflects fluid overpressure. Unlike the Muroto transect décollement, the splay fault system observed at Site $\mathrm{C0004}$ has permeable pathways for dewatering provided by the observed sand and coarse ash layers.

Sediments of the slope basin at Site C0008 provide a "reference site" for the sediments underthrust beneath the megasplay fault. Comparison of the interval 190-200 m CSF in Hole C0008A with an average porosity of $50 \%$ and the correlated interval 320$330 \mathrm{~m}$ CSF in Hole C0004D with an average porosity of $43 \%$ suggests the sediments are dewatering during underthrusting. Evidence for lateral flow is provided by $\mathrm{C}_{1} / \mathrm{C}_{2}$ ratios at Site $\mathrm{C0008}$ that are slightly lower than expected for biogenic production at the estimated in situ temperature. Lateral flow along sand layers could transmit fluids from where the temperature is higher because of greater burial underneath the splay fault.

These sand layers are truncated at a normal fault drilled in Hole C0008C, where surficial material has slid downward. Hole C0008C structural descriptions document normal faults within the sediments at $\sim 40$ $\mathrm{m}$ CSF. Lateral transmission of fluids from areas with thicker to thinner overburden has previously been suggested as a mechanism for enhancing slope failure (Dugan and Flemings, 2000). As a result, splay fault movement could produce slope failures through seaward propagation of pore pressures from 
the footwall in addition to oversteepening of the hanging wall. Postcruise examination of lithologic evidence, structural data, and physical properties will help assess the interaction between splay fault movement and slope failures.

Permeable pathways for consolidation and dewatering of the underthrust sediments could have implications for splay fault evolution. As these sediments dewater, drainage will affect the profile of effective stress in the section, resulting in a migrating zone of minimum mechanical strength. As this progresses through time, it is possible that the splay fault will migrate to less consolidated sediments (Moore and Byrne, 1987; Saffer, 2003).

Two steps of age reversal are tentatively recognized across the splay fault zone; this evidence suggests that fault-bounded Unit III at Site C0004 is a sliverlike unit coming up from a much deeper setting. The lithology of the slope sediments and the old accretionary prism in Hole C0008A suggests that one of the possible sources for the Unit III "sliver" at Site C0004 is the lowermost slope sediments beneath the Pleistocene and late Pliocene slope sediments. In this case, displacement along the splay fault, especially the lower boundary fault beneath Unit III, might be more than a couple of kilometers, which would require hundreds of large earthquakes, assuming meter-scale coseismic slip in this location (Tanioka and Satake, 2001; Kikuchi et al., 2003). Interestingly, porosity within this lithologic unit is slightly higher than expected relative to trends observed in overlying material. If these materials have been brought up from depth, they either never had an opportunity to consolidate or have subsequently had considerable opening of porosity by microfractures in this fault sliver.

Detailed analysis of the fault zone, including properties of the hanging wall, fault sliver, and footwall, is a main target of postcruise science to clarify the fault mechanism in the shallow splay fault.

\section{Accretionary prism and plate boundary frontal thrust}

The accretionary prism and frontal thrust cored during Expedition 316 (Sites C0006 and C0007) present unique features that are not observed in the Muroto and Ashizuri transects in the Nankai Trough or at other accretive margins such as the Barbados, Aleutian, or Cascadia margins.

The features are as follows:

1. The frontal thrust appears to have functioned as a plate boundary thrust for a long period, similar to the architecture observed along erosive margins, rather than systematic in-sequence thrust propagating mode within the accretionary prism, which is well observed in the Muroto transect and the Barbados Ridge.

2. Taper angle at the toe is the largest in the Nankai Trough (Kimura et al., 2007a) and similar to those in erosive margins (Clift and Vannucchi, 2004).

3. Seismic reflection profiles suggest that a new décollement appears to be forming within a layer beneath the trench wedge sediments (see Moore et al.).

4. Sandy and channel-filling coarse sediments are interpreted based on geophysical evidence to constitute most of the accretionary prism, and the same sediments fill the present trench wedge in the Nankai Trough.

How these characteristic features of the accretionary prism in this region are related to each other is unclear.

As a result of drilling at two sites (Holes C0006E, C0006F, and C0007A-C0007D), several new aspects of the accretion/subduction system have been revealed. The upper accretionary prism is composed of coarse terrigenous sediments, including gravel-dominated lithologies, whereas the lower part of the accretionary wedge is mud dominated. The upper and lower prism may be trench wedge to slope sediments and hemipelagic Shikoku Basin sediments, respectively; however, that interpretation must be confirmed by more detailed onshore analysis and results of planned drilling of sediments on the incoming plate. The modern trench wedge is composed of channelfilling deposits that are currently underthrusting beneath the accretionary prism. The plate boundary frontal thrust is located at a stratigraphic horizon of late Miocene mud, which appears to be similar to the Shikoku Basin facies that hosts the décollement in the Muroto and Ashizuri transects (Moore, Taira, Klaus, et al., 2001).

Lithologic Unit I sediments at Site C0006 are interpreted to represent a transition from trench to slope deposition; thus, the Unit I/II boundary records the uplift of trench material into the prism, and its age potentially provides a constraint on the timing of frontal thrust activity (Fig. F3). Unit I sediments are younger or the same age as sediments filling the basin behind the thrust. Based on biostratigraphy, the maximum age of the boundary is $\sim 0.9$ Ma. Taking into account the relative plate motion velocity between the overriding Japanese islands and the Philippine Sea plate, $\sim 4 \mathrm{~cm} / \mathrm{y}$ (Seno et al., 1993), the relative slip distance may be as much as $\sim 40 \mathrm{~km}$. No frontal accretion during this period means that the plate boundary frontal thrust has large displacement (total relative motion minus horizontal shortening of the accretionary prism). How such a large amount of slip has concentrated within the fault zone and how the evolution of the fault zone has affected the charac- 
teristic features in this region are two of the important issues of postcruise research.

The accretionary prism in the frontal thrust region is deformed by thrusting, as visible on the seismic profiles (Moore et al., 2007) and LWD data (Kinoshita et al., 2008). Most of the thrusts inferred from the seismic profiles and LWD data were confirmed from age reversals, fault zones sampled in cores, and repetition of specific strata, but some additional faults were also defined during Expedition 316 drilling. Chemical analysis of interstitial fluid and microbial habitat around most of these "intraprism" thrusts do not indicate any signal of active fluid flow.

In contrast to such intraprism thrusts, many normal faults are developed at the core scale and appear to be the youngest deformation feature. Clear slopeparallel mass sliding is observed from the submarine topography, seismic profiles, and shallow cores. These facts suggest that the taper angle of the prism is presently above the critical wedge taper angle and is unstable; there is evidence that the system is currently in a period of collapse. These preliminary interpretations of the frontal part of the accretionary prism have to be investigated from the physical and hydrological properties of accretionary prism material in postcruise research. The extremely low heat flow observed at Sites C0006 and C0007 might be related to stratigraphic or structural fluid pathways developed in this region. Porosity data suggest that a considerable thickness of material has been removed from the surface at Sites C0006 and C0007. Porosity is quite low at shallow depths below the surface, reaching $48 \%$ at 5 and $34 \mathrm{~m} \mathrm{CSF}$ at Sites C0006 and C0007, respectively. In contrast, porosity does not decrease to $<50 \%$ until $\sim 150$ or $\sim 200 \mathrm{~m}$ CSF, respectively, at prism Site $\mathrm{C0004}$ and slope basin Site C0008.

Frontal thrust fault zone sediments were successfully recovered, and preliminary visual core description shows shear localization and repeated slip in the fault zone; relationships between apparent repeated localized slip and coseismic and/or interseismic slip are a primary component of postcruise science research. Shipboard geochemical analyses suggest possible fluid flow around the frontal thrust. Episodicity of fluid flow and relationships between pore pressure and slip along the thrust are keys to understanding the dynamics of this part of accretionary prism and plate boundary thrust.

\section{Preliminary scientific assessment}

Expedition 316 successfully achieved the drilling objectives at the shallow megasplay fault and the frontal thrust. Site C0004, located seaward of the originally proposed site, was successfully cored during Expedition 316. Recovery conditions were difficult because the consolidation state and fractured nature of the prism was not ideal for either extended shoe coring system (ESCS) or rotary core barrel (RCB) coring. Recovery through the fault zone was increased by taking $4.5 \mathrm{~m}$ (rather than the typical $9.5 \mathrm{~m}$ ) cores. This method allowed successful recovery of fault zone samples, enabling description of the deformation surrounding the splay fault. In addition, samples were collected for multidisciplinary postcruise analysis. Whole-round cores were taken for postcruise geotechnical and hydrogeological studies; where these samples were unavailable because of brecciation, split core samples were collected. Testing of samples from beneath the splay fault will evaluate the consolidation state, mechanical properties, and hydrologic properties of the underthrust material. Results from Site C0004 underthrust sediments will be compared to data from correlated material at Site C0008. In addition, Expedition 316 results from Site C0004 will be integrated with LWD data (Expedition 314), and results from Kumano Basin drilling (Expedition 315) will also provide critical information on the timing of splay fault initiation.

The primary unachieved goal at the megasplay region was installment of casing for a future observatory. The casing was originally planned for Site C0003; during Expedition 314, the splay fault could not be reached at this site because of drilling conditions. Instead, Site C0004, which penetrated the splay fault at an estimated depth of $\sim 290$ m CSF, was selected as a replacement. The casing plan was not transferred to Site C0004 because of uncertainty as to whether its shallower depth would meet the observatory objectives. In addition, it was felt that if time allowed after completion of Sites C0004 and C0006, it would be scientifically more valuable to attempt a second, deeper crossing of the megasplay fault at $\sim 480 \mathrm{~m}$ CSF (which later turned out to be impossible because of time constraints) rather than to begin casing operations.

Drilling of the frontal thrust area provided the material to meet the Expedition 316 objectives in this area. Although Site C0006 did not reach the frontal thrust, it successfully captured several fault zones and characterized the lithologies, ages, deformation, pore fluid geochemistry, and physical properties of the hanging wall. Site $\mathrm{CO007}$ provided a clear view of the high-energy nature of the axial channel environment through recovery of very coarse grained deposits, including gravel. These coarse-grained sediments provide clues to the nature of material accreted into the prism. After moving to Hole C0007C, $\sim 185 \mathrm{~m}$ from Hole C0007A, to avoid a fault-thickened sec- 
tion of gravels, the frontal thrust was crossed. Through age reversals and structural observations, it is clear that a significant fault within the frontal thrust was recovered at Site $\mathrm{C0007}$ and that the recovered material documents shear localization.

$\mathrm{X}$-ray CT scan imaging proved to be extremely scientifically valuable during the cruise. It was used to ensure that critical intervals were not removed for whole-round samples for interstitial water or microbiological analyses. It was also crucial for identifying and measuring deformation structures that would otherwise have been masked by the splitting progress and for discerning natural from drilling-induced brecciation. Postcruise analyses of X-ray CT images will assist in structural analyses and evaluation of slump or slope failure deposits, potentially related to the seismogenic zone.

\section{References}

Ando, M., 1975. Source mechanisms and tectonic significance of historical earthquakes along the Nankai Trough, Japan. Tectonophysics, 27(2):119-140. doi:10.1016/0040-1951(75)90102-X

Ashi, J., Kuramoto, S., Morita, S., Tsunogai, U., Goto, S., Kojima, S., Okamoto, T., Ishimura, T., Ijiri, A., Toki, T., Kudo, S., Asai, S., and Utsumi, M., 2002. Structure and cold seep of the Nankai accretionary prism off Kumano-outline of the off Kumano survey during YK01-04 Leg 2 cruise. JAMSTEC J. Deep Sea Res., 20:1-8.

Baba, T., and Cummins, P.R., 2005. Contiguous rupture areas of two Nankai Trough earthquakes revealed by high-resolution tsunami waveform inversion. Geophys. Res. Lett., 32(8):L08305. doi:10.1029/2004GL022320

Baba, T., Cummins, P.R., Hori, T., and Kaneda, Y., 2006. High precision slip distribution of the 1944 Tonankai earthquake inferred from tsunami waveforms: possible slip on a splay fault. Tectonophysics, 426(1-2):119-134. doi:10.1016/j.tecto.2006.02.015

Byrne, D.E., Davis, D.M., and Sykes, L.R., 1988. Loci and maximum size of thrust earthquakes and the mechanics of the shallow region of subduction zones. Tectonics, 7(4):833-857. doi:10.1029/TC007i004p00833

Clift, P., and Vannucchi, P., 2004. Controls on tectonic accretion versus erosion in subduction zones: implications for the origin and recycling of the continental crust. Rev. Geophys., 42(2):RG2001. doi:10.1029/ 2003RG000127

Dugan, B., and Flemings, P.B., 2000. Overpressure and fluid flow in the New Jersey continental slope: implications for slope failure and cold seeps. Science, 289(5477):288-291. doi:10.1126/science.289.5477.288

Hickman, S., Zoback, M., and Ellsworth, W., 2004. Introduction to special section: preparing for the San Andreas Fault Observatory at depth. Geophys. Res. Lett., 31(12):L12S01. doi:10.1029/2004GL020688
Hori, T., Kato, N., Hirahara, K., Baba, T., and Kaneda, Y., 2004. A numerical simulation of earthquake cycles along the Nankai Trough in southwest Japan: lateral variation in frictional property due to the slab geometry controls the nucleation position. Earth Planet. Sci. Lett., 228(3-4):215-226. doi:10.1016/j.epsl.2004.09.033

Ichinose, G.A., Thio, H.K., Somerville, P.G., Sato, T., and Ishii, T., 2003. Rupture process of the 1944 Tonankai earthquake $\left(M_{S} 8.1\right)$ from the inversion of teleseismic and regional seismograms. J. Geophys. Res., 108(B10):2497. doi:10.1029/2003JB002393

Ito, Y., and Obara, K., 2006. Very low frequency earthquakes within accretionary prisms are very low stressdrop earthquakes. Geophys. Res. Lett., 33(9):L09302. doi:10.1029/2006GL025883

Kame, N., Rice, J.R., and Dmowska, R., 2003. Effects of prestress state and rupture velocity on dynamic fault branching. J. Geophys. Res., 108(B5):2265. doi:10.1029/ 2002JB002189

Kikuchi, M., Nakamura, M., and Yoshikawa, K., 2003. Source rupture processes of the 1944 Tonankai earthquake and the 1945 Mikawa earthquake derived from low-gain seismograms. Earth, Planets Space, 55(4):159172.

Kimura, G., Kitamura, Y., Hashimoto, Y., Yamaguchi, A., Shibata, T., Ujiie, K., and Okamoto, S., 2007a. Transition of accretionary wedge structures around the up-dip limit of the seismogenic subduction zone. Earth Planet. Sci. Lett., 225(3-4):471-484. doi:10.1016/ j.epsl.2007.01.005

Kimura, G., Screaton, E.J., and Curewitz, D., 2007b. NanTroSEIZE Stage 1: NanTroSEIZE shallow megasplay and frontal thrusts addendum. IODP Sci. Prosp., 316 addendum. doi:10.2204/iodp.sp.316add.2007

Kinoshita, M., Tobin, H., Moe, K.T., and the Expedition 314 Scientists, 2008. NanTroSEIZE Stage 1A: NanTroSEIZE LWD transect. IODP Prel. Rept., 314. doi:10.2204/ iodp.pr.314.2008

Lay, T., Kanamori, H., Ammon, C.J., Nettles, M., Ward, S.N., Aster, R.C., Beck, S.L., Bilek, S.L., Brudzinski, M.R., Butler, R., DeShon, H.R., Ekström, G., Satake, K., and Sipkin, S., 2005. The great Sumatra-Andaman earthquake of 26 December 2004. Science, 308(5725):11271133. doi: $10.1126 /$ science.1112250

Ma, K., 2005. Slip zone and energetic of a large earthquake from seismological modeling and fault core of TCDP. Eos, Trans. Am. Geophys. Union, 86(52):T43D-02. (Abstract)

Mikada, H., Moore, G.F., Taira, A., Becker, K., Moore, J.C., and Klaus, A. (Eds.), 2005. Proc. ODP, Sci. Results, 190/ 196: College Station, TX (Ocean Drilling Program). doi:10.2973/odp.proc.sr.190196.2005

Miyazaki, S., and Heki, K., 2001. Crustal velocity field of southwest Japan: subduction and arc-arc collision. J. Geophys. Res., 106(B3):4305-4326. doi:10.1029/ 2000JB900312

Moore, G.F., Bangs, N.L., Taira, A., Kuramoto, S., Pangborn, E., and Tobin, H.J., 2007. Three-dimensional splay fault geometry and implications for tsunami generation. Sci- 
ence, 318(5853):1128-1131. doi:10.1126/science.1147195

Moore, G.F., Taira, A., Klaus, A., Becker, L., Boeckel, B., Cragg, B.A., Dean, A., Fergusson, C.L., Henry, P., Hirano, S., Hisamitsu, T., Hunze, S., Kastner, M., Maltman, A.J., Morgan, J.K., Murakami, Y., Saffer, D.M., SánchezGómez, M., Screaton, E.J., Smith, D.C., Spivack, A.J., Steurer, J., Tobin, H.J., Ujiie, K., Underwood, M.B., and Wilson, M., 2001. New insights into deformation and fluid flow processes in the Nankai Trough accretionary prism: results of Ocean Drilling Program Leg 190. Geochem., Geophys., Geosyst., 2(10):1058. doi:10.1029/ 2001GC000166

Moore, G.F., Taira, A., Klaus, A., et al., 2001. Proc. ODP, Init. Repts., 190: College Station, TX (Ocean Drilling Program). doi:10.2973/odp.proc.ir.190.2001

Moore, J.C., and Byrne, T., 1987. Thickening of fault zones: a mechanism of melange formation in accreting sediments. Geology, 15(11):1040-1043. doi:10.1130/00917613(1987) 15<1040:TOFZAM>2.0.CO;2

Moore, J.C., and Saffer, D., 2001. Updip limit of the seismogenic zone beneath the accretionary prism of southwest Japan: an effect of diagenetic to low-grade metamorphic processes and increasing effective stress. Geology, 29(2):183-186. doi:10.1130/00917613(2001)029<0183:ULOTSZ>2.0.CO;2

Nakanishi, A., Takahashi, N., Park, J.-O., Miura, S., Kodaira, S., Kaneda, Y., Hirata, N., Iwasaki, T., and Nakamura, M., 2002. Crustal structure across the coseismic rupture zone of the 1944 Tonankai earthquake, the central Nankai Trough seismogenic zone. J. Geophys. Res., 107(B1):2007. doi:10.1029/2001JB000424

Obana, K., Kodaira, S., Mochizuki, K., and Shinohara, M., 2001. Micro-seismicity around the seaward updip limit of the 1946 Nankai earthquake dislocation area. Geophys. Res. Lett., 28(12):2333-2336. doi:10.1029/ 2000GL012794

Obara, K., Hirose, H., Yamamizu, F., and Kasahara, K., 2004. Episodic slow slip events accompanied by nonvolcanic tremors in southwest Japan subduction zone. Geophys. Res. Lett., 31(23):L23602. doi:10.1029/ 2004GL020848

Obara, K., and Ito, Y., 2005. Very low frequency earthquakes excited by the 2004 off the Kii Peninsula earthquakes: a dynamic deformation process in the large accretionary prism. Earth, Planets Space, 57(4):321-326.

Park, J.-O., Tsuru, T., Kodaira, S., Cummins, P.R., and Kaneda, Y., 2002. Splay fault branching along the Nankai subduction zone. Science, 297(5584):1157-1160. doi:10.1126/science.1074111

Plafker, G., 1972. Alaskan earthquake of 1964 and Chilean earthquake of 1960: implications for arc tectonics. $J$. Geophys. Res., 77(5):901-925. doi:10.1029/ JB077i005p00901
Ruff, L., and Kanamori, H., 1983. Seismic coupling and uncoupling at subduction zones. Tectonophysics, 99(24):99-117. doi:10.1016/0040-1951(83)90097-5

Saffer, D.M., 2003. Pore pressure development and progressive dewatering in underthrust sediments at the Costa Rican subduction margin: comparison with northern Barbados and Nankai. J. Geophys. Res., 108(B5):22612276. doi:10.1029/2002JB001787

Saffer, D.M., and Marone, C., 2003. Comparison of smectite- and illite-rich gouge frictional properties: application to the updip limit of the seismogenic zone along subduction megathrusts. Earth Planet. Sci. Lett., 215(12):219-235. doi:10.1016/S0012-821X(03)00424-2

Screaton, E., Saffer, D., Henry, P., and Hunze, S., 2002. Porosity loss within the underthrust sediments of the Nankai accretionary complex: implications for overpressures. Geology, 30(1):19-22. doi:10.1130/00917613(2002)030<0019:PLWTUS>2.0.CO;2

Seno, T., Stein, S., and Gripp, A.E., 1993. A model for the motion of the Philippine Sea plate consistent with NUVEL-1 and geological data. J. Geophys. Res., 98(B10):17941-17948. doi:10.1029/93JB00782

Shipboard Scientific Party, 2001a. Site 1173. In Moore, G.F., Taira, A., Klaus, A., et al., Proc. ODP, Init. Repts., 190: College Station, TX (Ocean Drilling Program), 1-147. doi:10.2973/odp.proc.ir.190.104.2001

Shipboard Scientific Party, 2001b. Site 1174. In Moore, G., Taira, A., Klaus, A., et al., Proc. ODP, Init. Repts., 190: College Station, TX (Ocean Drilling Program), 1-149. doi:10.2973/odp.proc.ir.190.105.2001

Tanioka, Y., and Satake, K., 2001. Detailed coseismic slip distribution of the 1944 Tonankai earthquake estimated from tsunami waveforms. Geophys. Res. Lett., 28(6):1075-1078. doi:10.1029/2000GL012284

Tobin, H.J., and Kinoshita, M., 2006a. Investigations of seismogenesis at the Nankai Trough, Japan. IODP Sci. Prosp., NanTroSEIZE Stage 1. doi:10.2204/ iodp.sp.nantroseize1.2006

Tobin, H.J., and Kinoshita, M., 2006b. NanTroSEIZE: the IODP Nankai Trough Seismogenic Zone Experiment. Sci. Drill., 2:23-27. doi:10.2204/iodp.sd.2.06.2006

Wang, K., and $\mathrm{Hu}, \mathrm{Y} ., 2006$. Accretionary prisms in subduction earthquake cycles: the theory of dynamic Coulomb wedge. J. Geophys. Res., 111(B6):B06410. doi:10.1029/ 2005JB004094

Yamano, M., Kinoshita, M., Goto, S., and Matsubayashi, O., 2003. Extremely high heat flow anomaly in the middle part of the Nankai Trough. Phys. Chem. Earth, 28(911):487-497. doi:10.1016/S1474-7065(03)00068-8

Publication: 11 March 2009 MS 314315316-131 
Figure F1. A. Nankai Trough off southwestern Japan, locus of Philippine Sea plate (PSP) subduction beneath Honshu and Shikoku islands. Yellow arrow $=$ convergence direction between PSP and Japan. Rupture zones of 1944 and 1946 earthquakes are also shown. Stars = epicenter locations for earthquake nucleation. Red dashed box $=$ area shown in $\mathrm{B}$. In inset, $\mathrm{EP}=$ Eurasian plate, $\mathrm{PP}=$ Pacific plate, $\mathrm{NAP}=$ North American plate. (Continued on next page.)

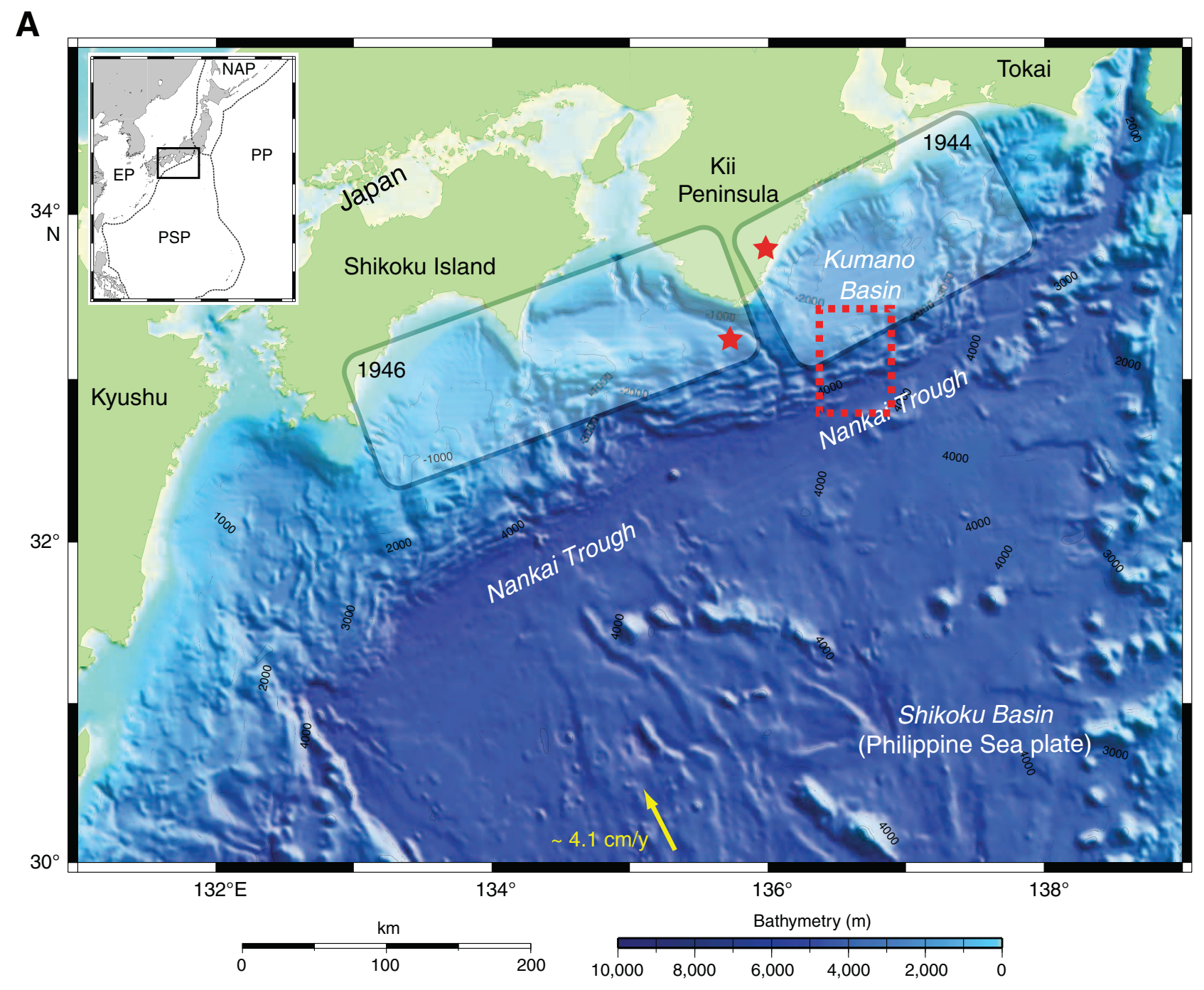


Figure F1 (continued). B. Locations of four drilling sites occupied during Expedition 316.

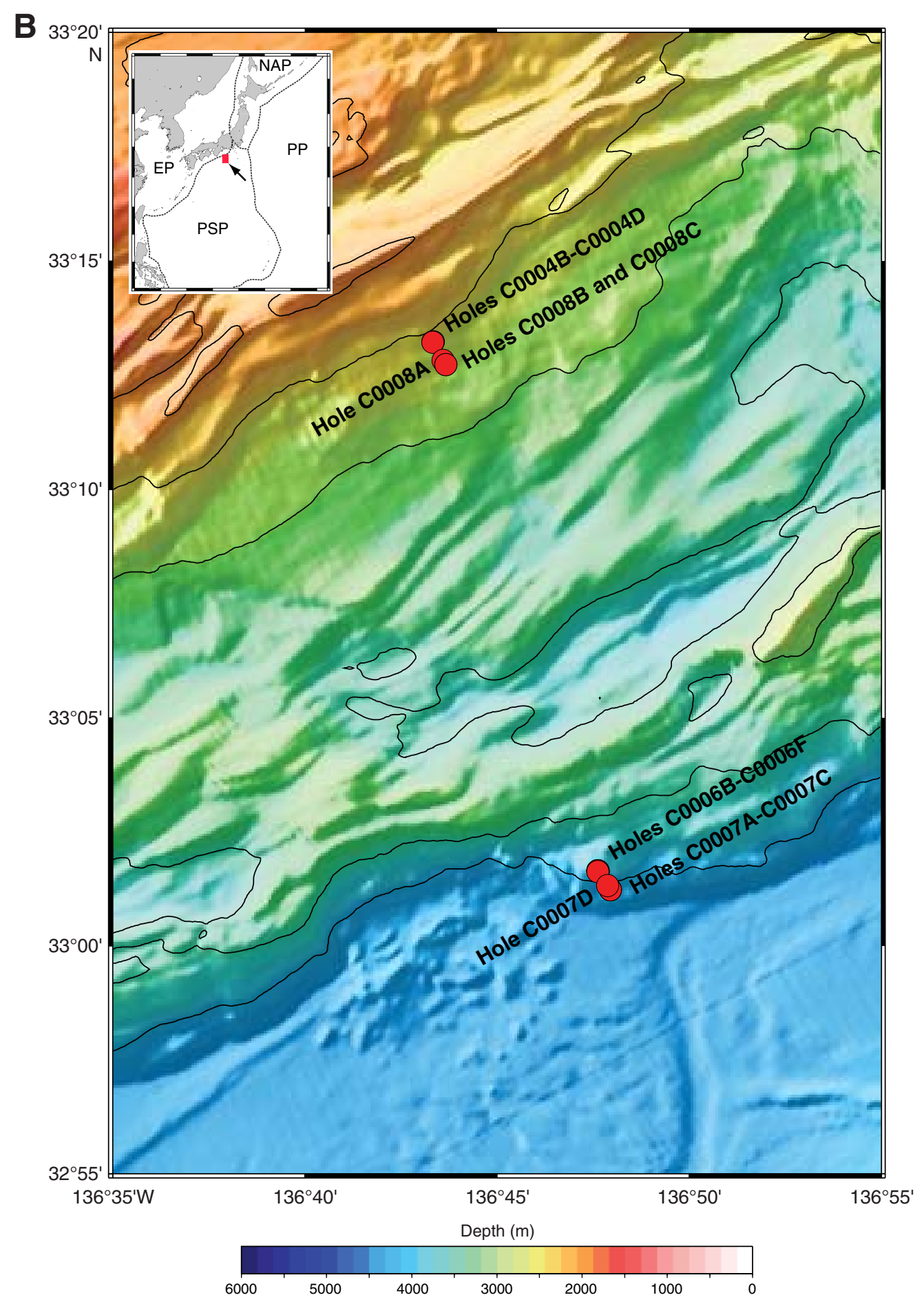


Figure F2. Depth section of 3-D seismic profile along the drilled sites (Moore et al., 2007). Note that section is an arbitrary line through the 3-D seismic volume to pass through all drill sites. $\mathrm{VE}=$ vertical exaggeration.

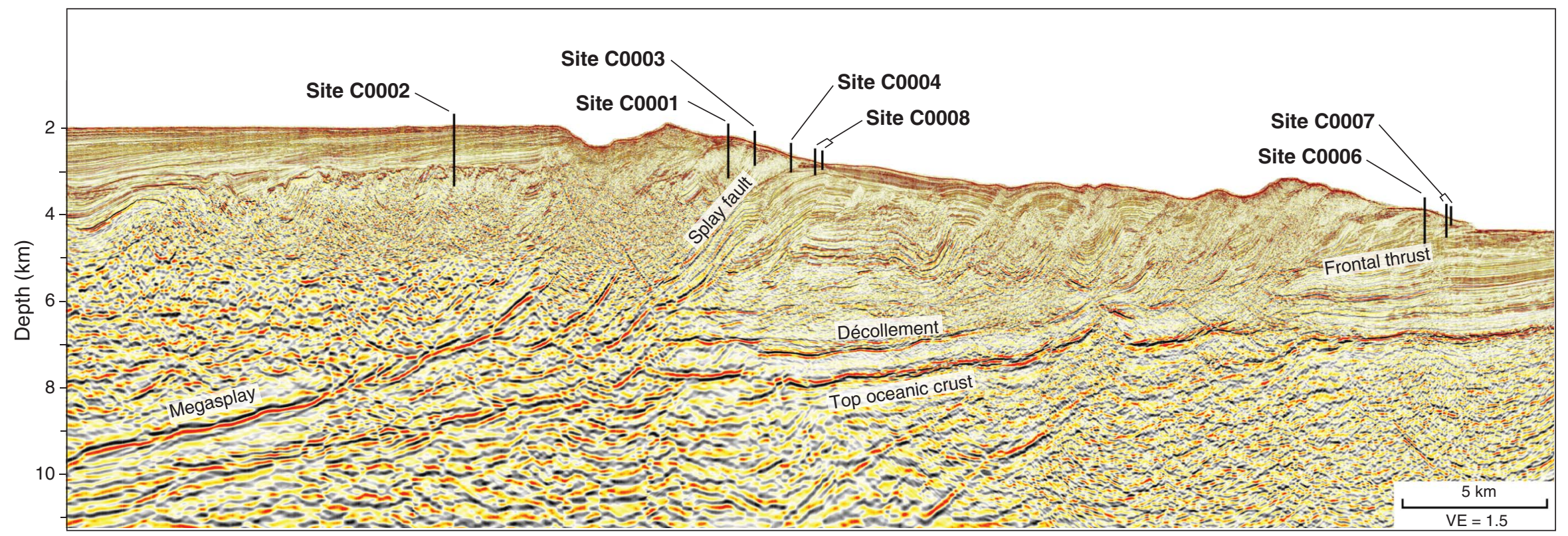




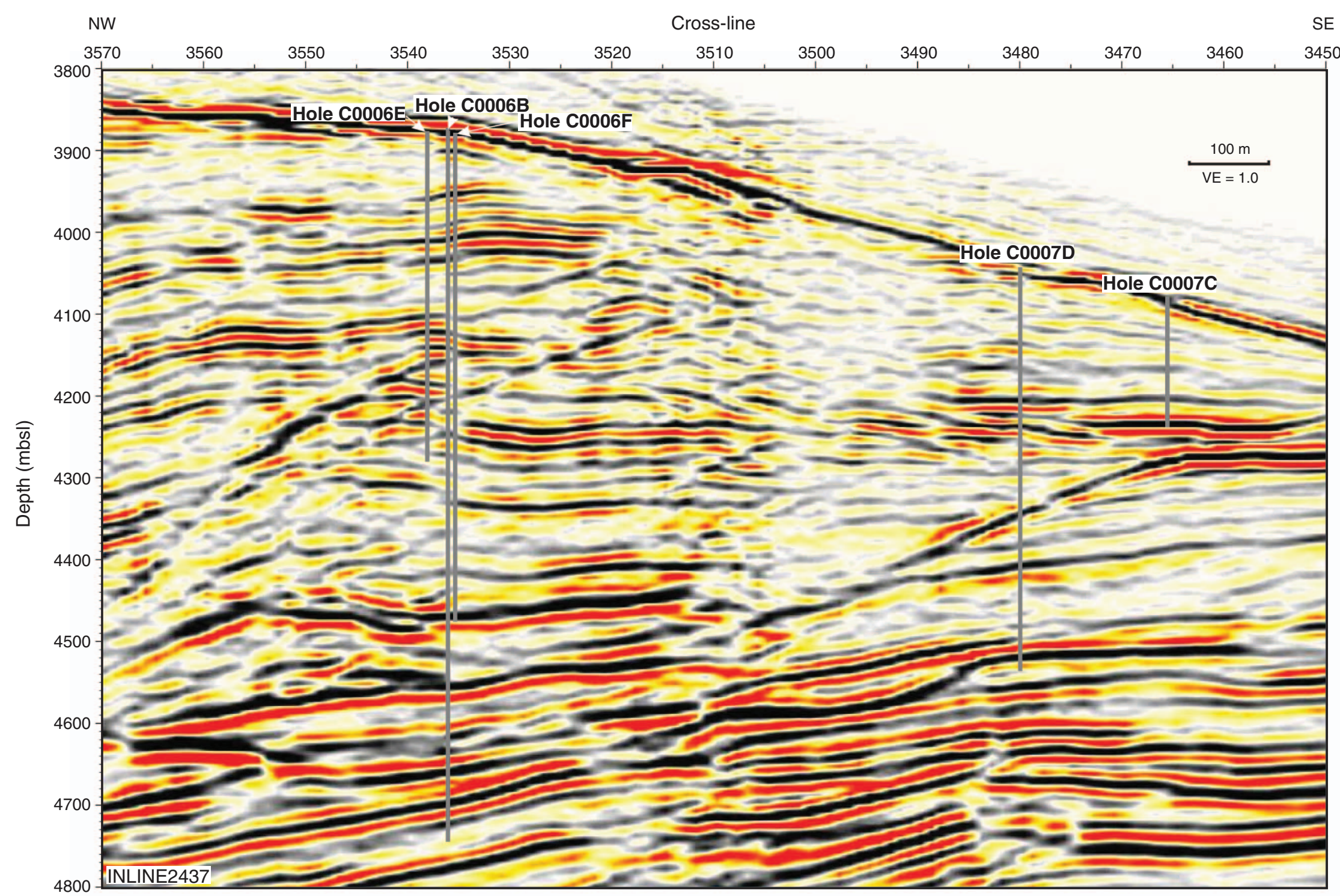


Figure F4. 3-D seismic profile crossing Sites C0004 and C0008 (Moore et al., 2007). VE = vertical exaggeration.

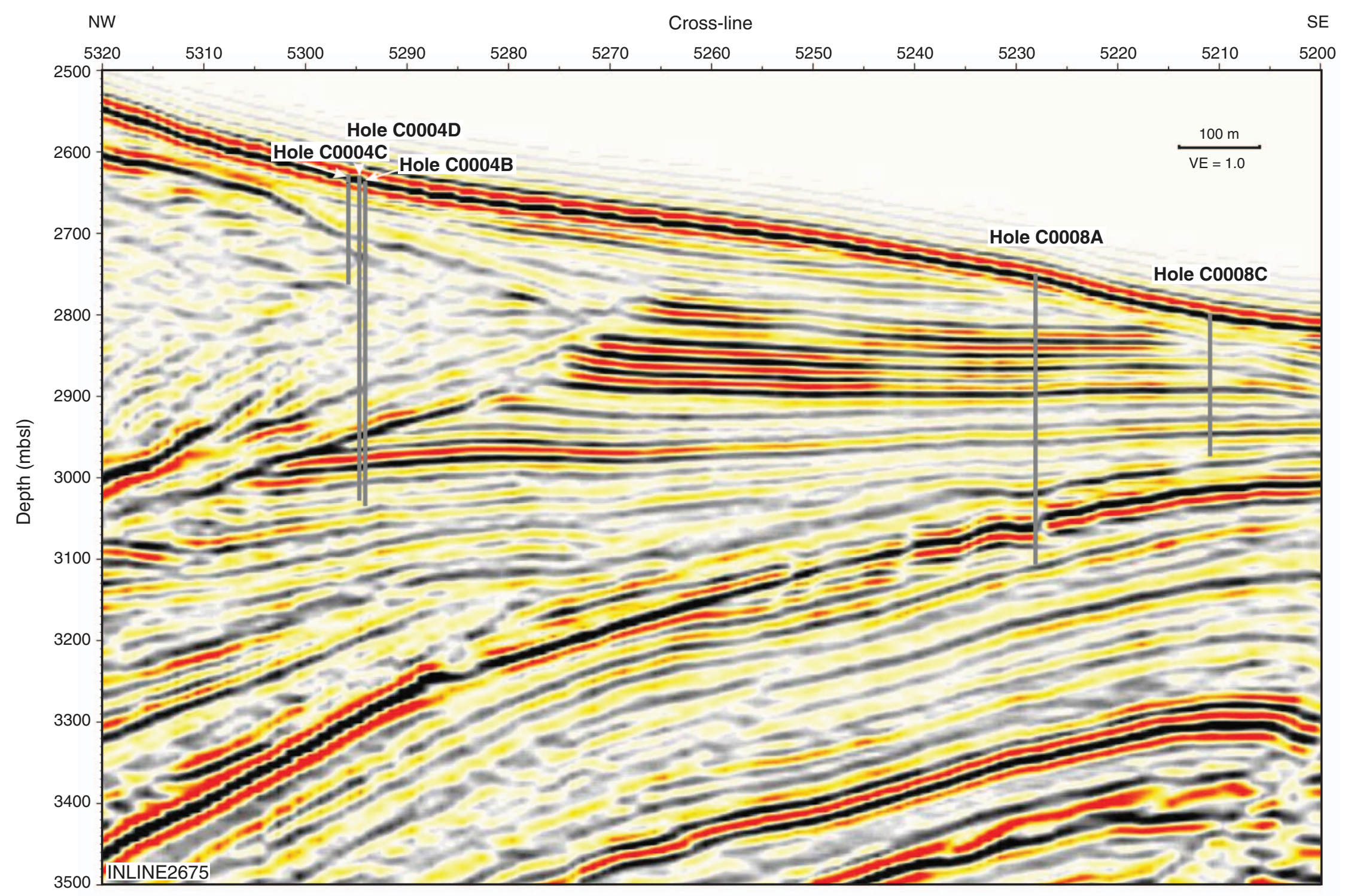


Figure F5. Site C0004 summary results, Holes C0004C and C0004D. Shaded area $=$ splay fault zone. CSF $=$ core depth below seafloor.

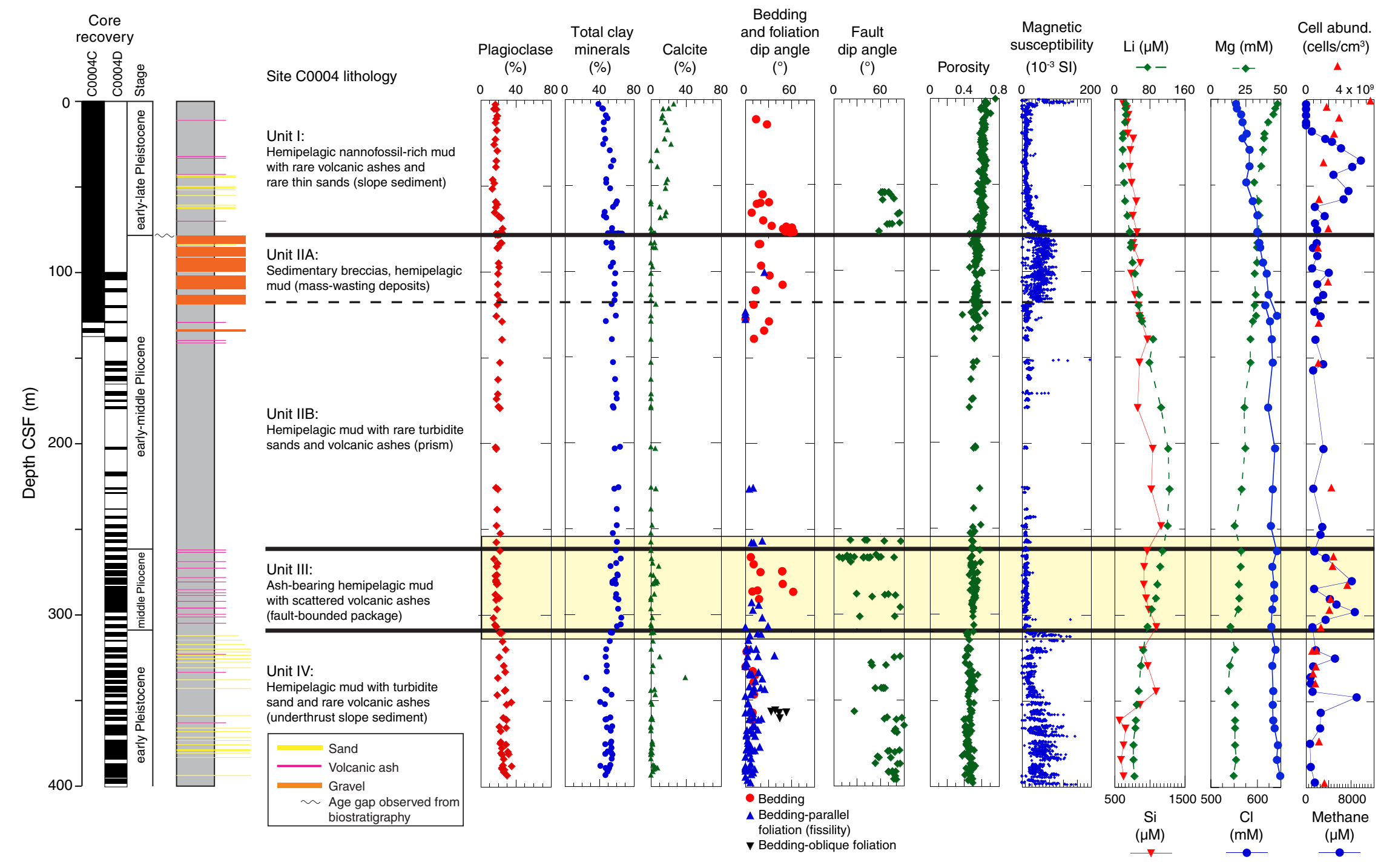


Figure F6. Site C0006 summary results, Holes C0006C-C0006F. CSF = core depth below seafloor, LWD = logging-while-drilling, WR = whole-round.

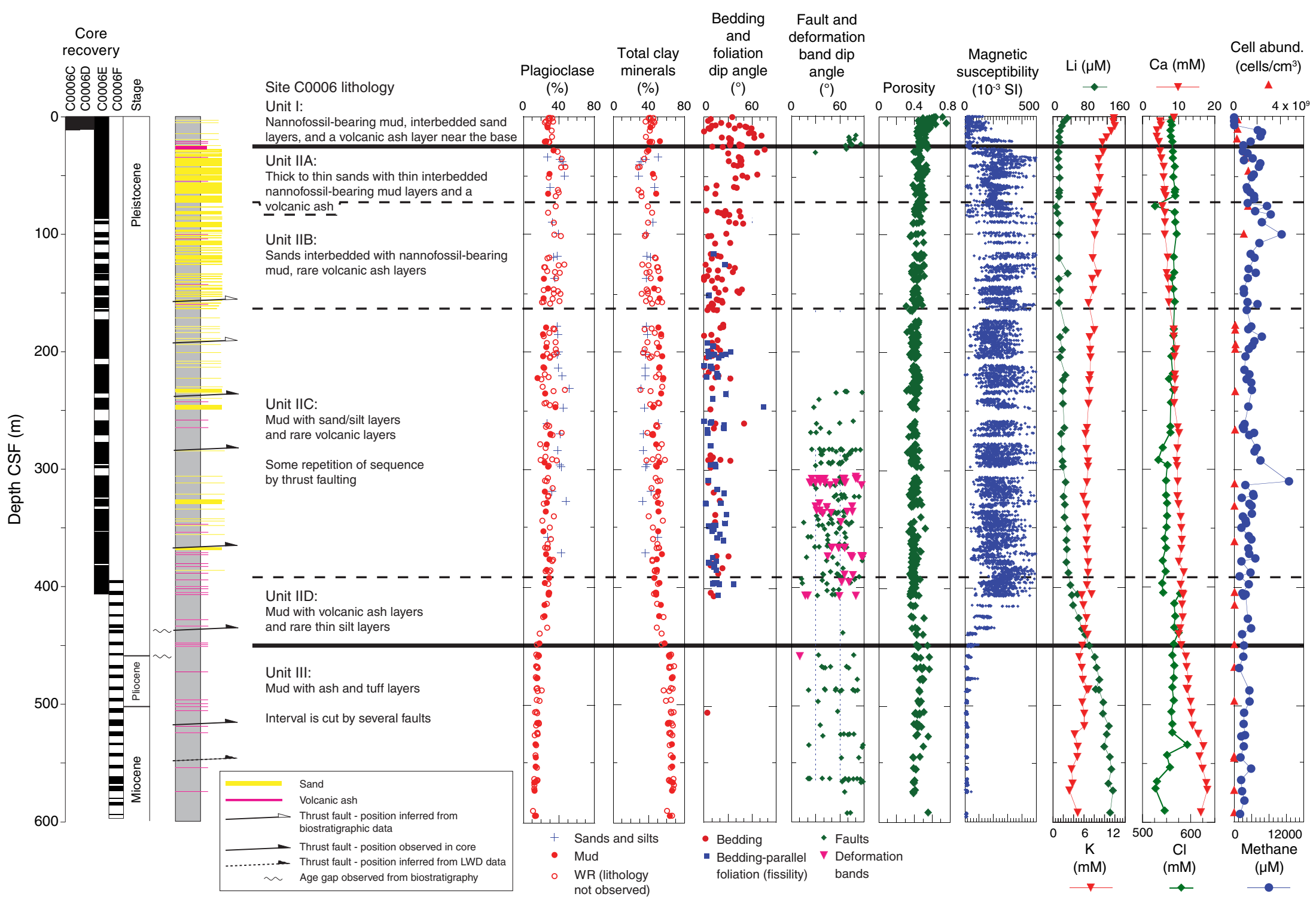


Figure F7. Site C0007 summary results. Because of the distance $(185 \mathrm{~m})$ and prism thickening between Holes C0007A-C0007C and C0007D, they are not combined. $\mathrm{CSF}=$ core depth below seafloor.

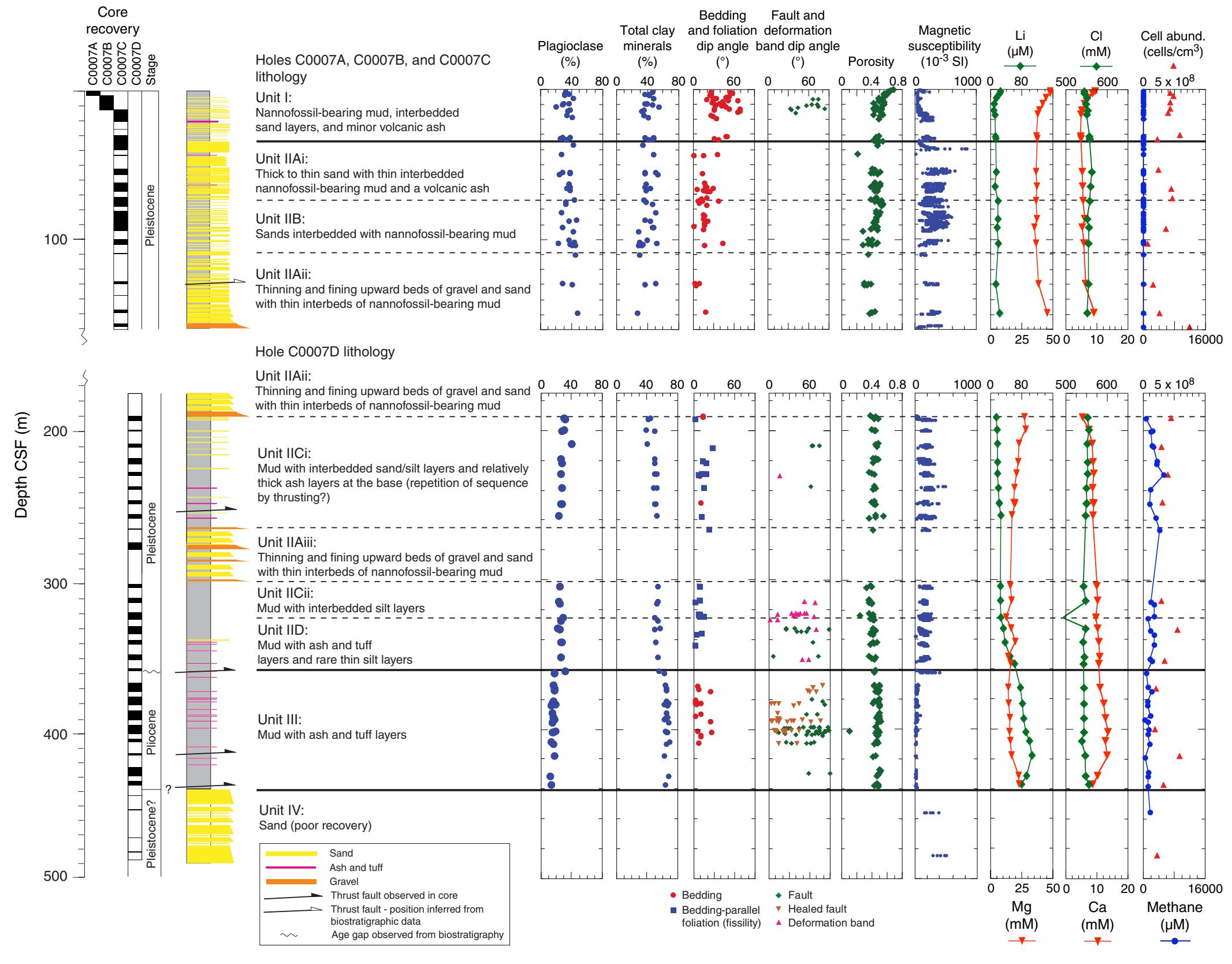


Figure F8. Site C0008 summary results. Because of the distance (215 m) and possible normal faulting between Holes C0008A and C0008B-C0008C, they are not combined. CSF = core depth below seafloor.
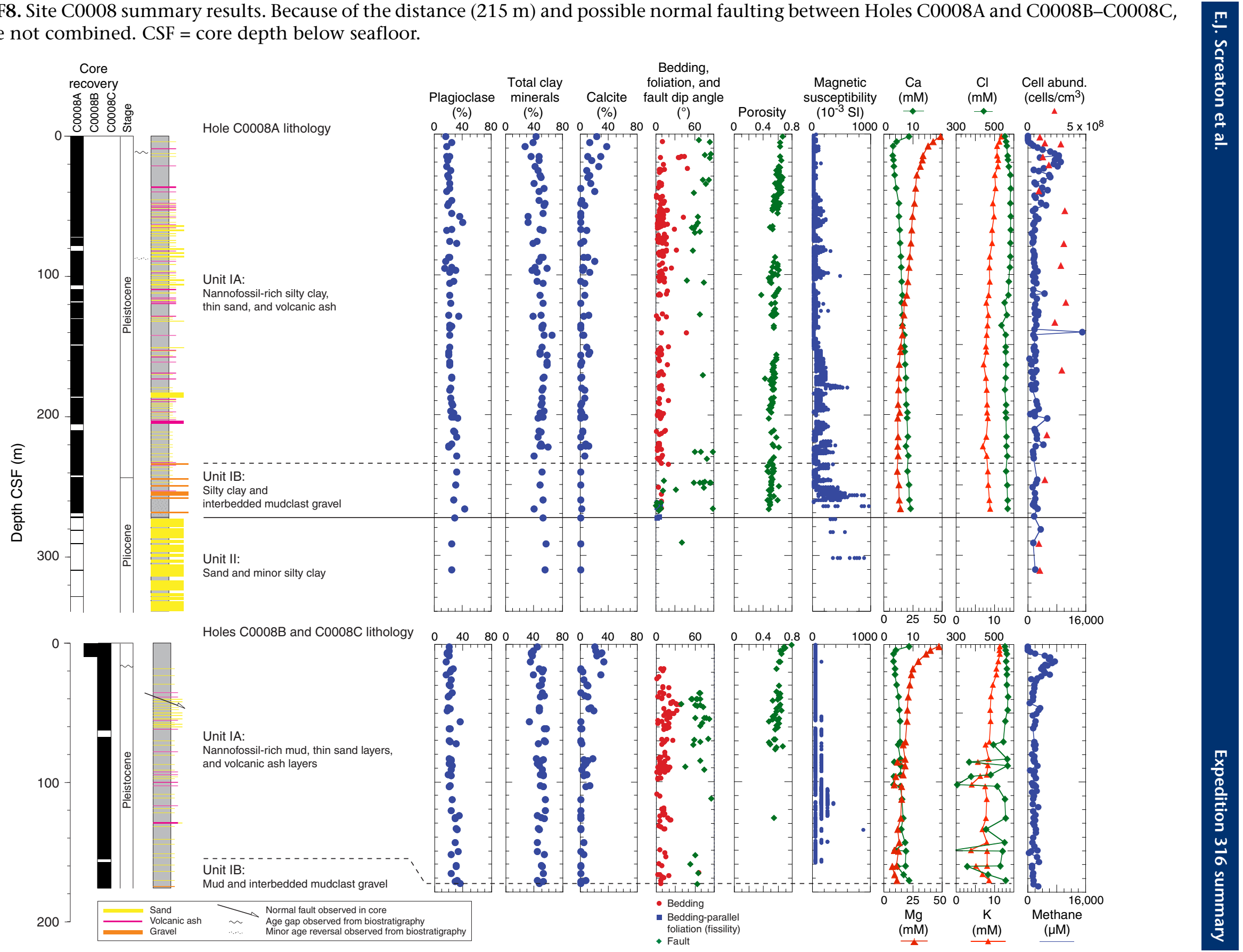
Table T1. Operations summary, Expedition 316.

\begin{tabular}{|c|c|c|c|c|c|c|c|c|}
\hline Hole & Location & $\begin{array}{l}\text { Water } \\
\text { depth } \\
\text { (mbsl) }\end{array}$ & $\begin{array}{l}\text { Cores } \\
(N)\end{array}$ & $\begin{array}{l}\text { Cored } \\
(\mathrm{m})\end{array}$ & $\begin{array}{l}\text { Recovered } \\
(\mathrm{m})\end{array}$ & $\begin{array}{l}\text { Recovery } \\
\text { (\%) }\end{array}$ & $\begin{array}{l}\text { Drilled } \\
(\mathrm{m})\end{array}$ & $\begin{array}{l}\text { Penetration } \\
\text { (m) }\end{array}$ \\
\hline C0004C & $33^{\circ} 13.2278^{\prime} \mathrm{N}, 136^{\circ} 43.3312^{\prime} \mathrm{E}$ & 2627.0 & 18 & 131.3 & 135.23 & 102.31 & 135.0 & 135.00 \\
\hline \multirow{2}{*}{ C0004D } & $33^{\circ} 13.2190^{\prime} \mathrm{N}, 136^{\circ} 43.3287^{\prime} \mathrm{E}$ & 2630.5 & 56 & 300.0 & 130.76 & 43.59 & 400.0 & 400.00 \\
\hline & Site $\mathrm{C} 00$ & 04 totals: & 74 & 431.3 & 265.99 & 61.67 & 535.0 & 535.00 \\
\hline $\mathrm{C} 0006 \mathrm{C}$ & $33^{\circ} 01.6458^{\prime} \mathrm{N}, 136^{\circ} 47.6282^{\prime} \mathrm{E}$ & 3880.5 & 1 & 9.5 & 10.26 & 108.00 & 9.5 & 9.50 \\
\hline C0006D & $33^{\circ} 01.6431^{\prime} \mathrm{N}, 136^{\circ} 47.6282^{\prime} \mathrm{E}$ & 3877.5 & 1 & 9.5 & 10.20 & 107.37 & 9.5 & 9.50 \\
\hline C0006E & $33^{\circ} 01.6444^{\prime} \mathrm{N}, 136^{\circ} 47.6282^{\prime} \mathrm{E}$ & 3875.8 & 49 & 409.4 & 330.32 & 80.68 & 409.4 & 409.44 \\
\hline \multirow[t]{2}{*}{$\mathrm{C} 0006 \mathrm{~F}$} & $33^{\circ} 01.6242^{\prime} \mathrm{N}, 136^{\circ} 47.6282^{\prime} \mathrm{E}$ & 3875.5 & 23 & 208.0 & 56.48 & 27.15 & 208.0 & 208.00 \\
\hline & Site C00 & 06 totals: & 74 & 636.4 & 407.26 & 63.99 & 636.4 & 636.44 \\
\hline C0007A & $33^{\circ} 01.2326^{\prime} \mathrm{N}, 136^{\circ} 47.9485^{\prime} \mathrm{E}$ & 4081.0 & 1 & 3.1 & 3.14 & 100.00 & 3.1 & 3.14 \\
\hline C0007B & $33^{\circ} 01.2326^{\prime} \mathrm{N}, 136^{\circ} 47.9485^{\prime} \mathrm{E}$ & 4081.0 & 1 & 9.5 & 10.03 & 105.58 & 12.6 & 12.64 \\
\hline C0007C & $33^{\circ} 01.2326^{\prime} \mathrm{N}, 136^{\circ} 47.9485^{\prime} \mathrm{E}$ & 4081.0 & 18 & 163.5 & 59.31 & 36.29 & 176.1 & 176.09 \\
\hline \multirow[t]{2}{*}{ C0007D } & $33^{\circ} 01.3167^{\prime} \mathrm{N}, 136^{\circ} 47.8872^{\prime} \mathrm{E}$ & 4049.0 & 35 & 318.5 & 87.93 & 27.61 & 493.5 & 493.50 \\
\hline & Site $\mathrm{C} 00$ & 07 totals: & 55 & 494.6 & 160.41 & 32.43 & 685.4 & 685.37 \\
\hline C0008A & $33^{\circ} 12.8229^{\prime} \mathrm{N}, 136^{\circ} 43.5997^{\prime} \mathrm{E}$ & 2751.0 & 43 & 357.8 & 271.20 & 75.81 & 357.8 & 357.75 \\
\hline C0008B & $33^{\circ} 12.7313^{\prime} \mathrm{N}, 136^{\circ} 43.6727^{\prime} \mathrm{E}$ & 2797.0 & 1 & 9.5 & 9.82 & 103.40 & 9.5 & 9.50 \\
\hline \multirow[t]{3}{*}{ C0008C } & $33^{\circ} 12.7313^{\prime} \mathrm{N}, 136^{\circ} 43.6727^{\prime} \mathrm{E}$ & 2797.0 & 25 & 176.2 & 189.66 & 108.00 & 176.2 & 176.20 \\
\hline & Site C00 & 08 totals: & 69 & 543.5 & 470.68 & 86.61 & 543.5 & 543.45 \\
\hline & Expedition 3 & 16 totals: & 272 & 2105.8 & 1304.34 & 61.94 & 2400.3 & 2400.26 \\
\hline
\end{tabular}


Table T2. Temperature tool deployments, Expedition 316. (See table note.)

\begin{tabular}{|c|c|c|c|c|}
\hline Hole, core & $\begin{array}{l}\text { Depth } \\
\text { (mbsf) }\end{array}$ & $\begin{array}{c}\text { Extrapolated } \\
\text { temperature }\left({ }^{\circ} \mathrm{C}\right)\end{array}$ & $\begin{array}{l}\text { Temperature } \\
\text { tool }\end{array}$ & $\begin{array}{l}\text { Solution } \\
\text { reliability }\end{array}$ \\
\hline C0004C-3H & 25.38 & 3.24 & АРCT3 & Good \\
\hline $\mathrm{C} 0004 \mathrm{C}-6 \mathrm{H}$ & 53.88 & 4.77 & АРСТ 3 & Good \\
\hline $\mathrm{COOO4C-9H}$ & 80.84 & 6.42 & АРCT3 & Good \\
\hline C0004C-18H & 135.00 & 8.86 & APCT3 & Good \\
\hline C0006E-3H & 24.19 & 2.85 & АРCT3 & Good \\
\hline C0006E-5H & 38.52 & 3.00 & АРСТ 3 & Good \\
\hline C0006E-8H & 57.69 & No usable data & АРCT3 & Failure \\
\hline C0006E-10H & 64.70 & 3.75 & АРCT3 & Good \\
\hline C0006E-14H & 79.33 & No usable data & АРCT3 & Failure \\
\hline C0006E-16X (bottom) & 98.33 & 4.82 & DVTP & Fair \\
\hline C0006E-23X (bottom) & 163.33 & No data & DVTP & Failure \\
\hline C0006E-26X (bottom) & 191.83 & No data & DVTP & Failure \\
\hline C0006E-28X (bottom) & 210.83 & No data & DVTP & Failure \\
\hline C0006E-29X (bottom) & 220.33 & 7.87 & DVTP & Fair \\
\hline C0006E-35X (bottom) & 277.33 & No usable data & DVTP & Failure \\
\hline C0006E-42X (bottom) & 343.83 & No usable data & DVTP & Failure \\
\hline C0007B-1H & 12.64 & 2.42 & АРCT3 & Good \\
\hline $\mathrm{C} 0007 \mathrm{C}-2 \mathrm{H}$ & 30.09 & 3.23 & АРСТ 3 & Good \\
\hline C0007C-4H & 43.09 & 4.02 & АРCT3 & Good \\
\hline C0007C-5X (bottom) & 52.59 & 4.14 & SET & Good \\
\hline C0007C-8X (bottom) & 81.09 & 5.43 & SET & Good \\
\hline C0008A-3H & 25.00 & 3.31 & АРСТ3 & Poor \\
\hline $\mathrm{C} 0008 \mathrm{~A}-6 \mathrm{H}$ & 53.50 & 4.73 & АРCT3 & Good \\
\hline C0008A-9H & 82.00 & No usable data & АРСТ 3 & Failure \\
\hline C0008A-11H & 100.00 & 8.18 & АРСТ3 & Poor \\
\hline C0008A-13H & 119.00 & 8.35 & АРCT3 & Poor \\
\hline C0008A-16H & 130.89 & 8.46 & АРСТ 3 & Fair \\
\hline C0008A-19H & 152.70 & 9.16 & АРCT3 & Good \\
\hline C0008A-22H & 177.73 & 11.63 & АРСТ3 & Good \\
\hline C0008A-25H & 200.89 & 12.60 & АРCT3 & Good \\
\hline C0008A-30X (bottom) & 243.75 & 14.60 & SET & Fair \\
\hline $\mathrm{C} 0008 \mathrm{C}-3 \mathrm{H}$ & 24.51 & 3.41 & АРСТ3 & Good \\
\hline C0008C-5H & 43.51 & 4.60 & АРCT3 & Good \\
\hline C0008C-7H & 60.51 & 5.22 & АРCT3 & Good \\
\hline C0008C-9H & 73.51 & 6.44 & АРСТ 3 & Good \\
\hline C0008C-11H & 90.11 & 7.39 & АРCT3 & Good \\
\hline C0008C-13H & 97.59 & 7.69 & АРCT3 & Good \\
\hline C0008C-15H & 108.29 & 7.73 & АРСТ 3 & Good \\
\hline C0008C-17H & 119.89 & 8.72 & АРCT3 & Good \\
\hline C0008C-19H & 129.39 & 9.62 & АРСТ 3 & Good \\
\hline C0008C-21H & 139.00 & 10.07 & АРСТЗ & Good \\
\hline
\end{tabular}

Note: APCT3 = advanced piston coring temperature tool, DVTP = Davis-Villinger Temperature Probe, SET = sediment temperature. 